\title{
Differential neurovirulence of Usutu virus lineages in mice and neuronal cells
}

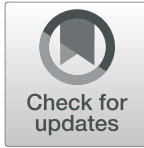

Marion Clé ${ }^{1 \dagger}$, Orianne Constant ${ }^{1 \dagger}$, Jonathan Barthelemy ${ }^{1}$, Caroline Desmetz $^{2}$, Marie France Martin ${ }^{3}$, Lina Lapeyre ${ }^{3}$, Daniel Cadar ${ }^{4}$, Giovanni Savini ${ }^{5}$, Liana Teodori ${ }^{5}$, Federica Monaco ${ }^{5}$, Jonas Schmidt-Chanasitt, ${ }^{4,6}$ Juan-Carlos Saiz ${ }^{7}$, Gaëlle Gonzales ${ }^{8}$, Sylvie Lecollinet ${ }^{8}$, Cécile Beck ${ }^{8}$, Fabien Gosselet ${ }^{9}$, Philippe Van de Perre ${ }^{1,10}$,

Vincent Foulongne ${ }^{1,10}$, Sara Salinas ${ }^{1}$ and Yannick Simonin ${ }^{*^{*}}$ (i)

\begin{abstract}
Background: Usutu virus (USUV) is an emerging neurotropic arthropod-borne virus recently involved in massive die offs of wild birds predominantly reported in Europe. Although primarily asymptomatic or presenting mild clinical signs, humans infected by USUV can develop neuroinvasive pathologies (including encephalitis and meningoencephalitis). Similar to other flaviviruses, such as West Nile virus, USUV is capable of reaching the central nervous system. However, the neuropathogenesis of USUV is still poorly understood, and the virulence of the specific USUV lineages is currently unknown. One of the major complexities of the study of USUV pathogenesis is the presence of a great diversity of lineages circulating at the same time and in the same location.

Methods: The aim of this work was to determine the neurovirulence of isolates from the six main lineages circulating in Europe using mouse model and several neuronal cell lines (neurons, microglia, pericytes, brain endothelial cells, astrocytes, and in vitro Blood-Brain Barrier model).

Results: Our results indicate that all strains are neurotropic but have different virulence profiles. The Europe 2 strain, previously described as being involved in several clinical cases, induced the shortest survival time and highest mortality in vivo and appeared to be more virulent and persistent in microglial, astrocytes, and brain endothelial cells, while also inducing an atypical cytopathic effect. Moreover, an amino acid substitution (D3425E) was specifically identified in the RNA-dependent RNA polymerase domain of the NS5 protein of this lineage.

Conclusions: Altogether, these data show a broad neurotropism for USUV in the central nervous system with lineage-dependent virulence. Our results will help to better understand the biological and epidemiological diversity of USUV infection.
\end{abstract}

Keywords: Usutu virus, Arbovirus, Flavivirus, Neurotropism, Central nervous system

\section{Background}

Usutu virus (USUV) is an arbovirus of the genus Flavivirus from the Flaviviridae family. It belongs to the Japanese encephalitis virus (JEV) antigenic complex isolated

\footnotetext{
*Correspondence: yannick.simonin@umontpellier.fr

${ }^{+}$Marion Clé and Orianne Constant contributed equally to this work.

'Pathogenesis and Control of Chronic Infections, Université de Montpellier, INSERM, EFS, Montpellier, France

Full list of author information is available at the end of the article
}

for the first time in 1959 from Culex neavei (trapped in Swaziland) after intracerebral inoculation of newborn mice in Southern Africa [1-4]. Over recent years, this emerging virus has dispersed out of Africa mainly into Europe [5]. It was presumably carried by migratory birds and their associated mosquitoes, such as Culex pipiens [6-9]. Similar to other flaviviruses, USUV is an icosahedral-enveloped virus with a single-stranded positive sense RNA of $11 \mathrm{~kb}$, with a $5^{\prime}$ cap structure and one

(c) The Author(s). 2021, corrected publication 2021. Open Access This article is licensed under a Creative Commons Attribution 4.0 International License, which permits use, sharing, adaptation, distribution and reproduction in any medium or format, as long as you give appropriate credit to the original author(s) and the source, provide a link to the Creative Commons licence, and indicate if changes were made. The images or other third party material in this article are included in the article's Creative Commons licence, unless indicated otherwise in a credit line to the material. If material is not included in the article's Creative Commons licence and your intended use is not permitted by statutory regulation or exceeds the permitted use, you will need to obtain permission directly from the copyright holder. To view a copy of this licence, visit http://creativecommons.org/ licenses/by/4.0/. The Creative Commons Public Domain Dedication waiver (http://creativecommons.org/publicdomain/zero/1. 0/) applies to the data made available in this article, unless otherwise stated in a credit line to the data. 
open reading frame (ORF) encoding a polyprotein of 3434 amino acids. The USUV polyprotein is posttranslationally processed by cellular and viral proteases into three structural proteins: capsid (C), premembrane/membrane (prM/M), and envelope (E), and seven nonstructural proteins (NS1, NS2A, NS2B, NS3, NS4A, NS4B, and NS5) [10]. Its natural life cycle mainly involves birds (like Strigiformes or Passeriformes) and mosquitoes (mainly Culex) [11].

USUV infection of birds is frequently characterized by encephalitis, myocardial degeneration, and necrosis of the brain, liver, and spleen $[6,12]$. Humans and others mammals, such as horses, rodents, dogs, and wild boars, are considered accidental hosts [13-17]. The first two cases of USUV infection in humans were described in Africa, precisely in Central African Republic (1981) and Burkina Faso (2004), with mild symptoms such as fever and rash [18]. In Europe, USUV infection was reported for the first time in 2009 in two patients in Italy [1921]. Since then, several studies have reported human infections in Italy associated with neurological damages
[22-27]. In 2013 and 2018, six patients with neuroinvasive symptoms (meningitis and meningoencephalitis) were diagnosed in Croatia, and a patient with aseptic meningitis in Hungary [28-30]. In 2016, USUV infection was reported in France in a patient with idiopathic facial paralysis [31]. In addition, USUV was detected in asymptomatic human blood donors in Austria, Germany, and the Netherlands [32-36]. To date, 100 cases of acute human infection have been described, mainly in Europe including patients with neurological symptoms (Table 1). Major USUV epizootics affecting avifauna, associated with a large epidemic of West Nile virus (WNV), were demonstrated in Europe in 2016 and in 2018 [37].

Isolates of USUV are currently classified into eight different genetic lineages which are divided in two major African or European groups: Africa (AF) 1, 2, and 3 and Europe (EU) 1, 2, 3, 4, and $5[38,39]$. Although the great USUV evolutionary diversity in Europe appears to have emerged in the last decade, phylogeny analyses suggest relatively long-term circulation of USUV in Europe. As shown in Table 1, human cases of USUV infection are

Table 1 Description of human cases of USUV infection worldwide

\begin{tabular}{|c|c|c|c|c|c|c|c|}
\hline Country & Year & Number & Sample & Clinical signs & Studied population & Identified strains & Ref \\
\hline CAR & 1981 & 1 & Blood & Eruptive fever & Clinical case & Africa 3 & [18] \\
\hline $\begin{array}{l}\text { Burkina } \\
\text { Faso }\end{array}$ & 2004 & 1 & Blood & Fever and jaundice & Clinical case & $?$ & [18] \\
\hline \multirow[t]{8}{*}{ Italy } & 2009 & 1 & CSF & Meningoencephalitis & Clinical case & Europe 1 & [19] \\
\hline & 2009 & 1 & Blood & Encephalitis & Clinical case & Europe 2 & $\begin{array}{l}{[20,} \\
21]\end{array}$ \\
\hline & $\begin{array}{l}2008- \\
2009\end{array}$ & $3 / 44$ & CSF & Meningoencephalitis & Meningoencephalitis patients & $?$ & {$[22]$} \\
\hline & $\begin{array}{l}2008- \\
2011\end{array}$ & $\begin{array}{l}8 / 306+ \\
2 / 609\end{array}$ & $\begin{array}{l}\text { CSF / } \\
\text { Blood }\end{array}$ & Meningoencephalitis / Healthy & $\begin{array}{l}\text { Meningoencephalitis patients (CSF). various } \\
\text { healthy and sick subjects (serum) }\end{array}$ & $?$ & [23] \\
\hline & 2018 & $1 / 44$ & Blood & Healthy & Blood donors & Europe 1 & {$[24]$} \\
\hline & $\begin{array}{l}2016- \\
2018\end{array}$ & $\begin{array}{l}25 / \\
73964\end{array}$ & Blood & Healthy & Blood donors & $?$ & {$[25]$} \\
\hline & $\begin{array}{l}2017- \\
2018\end{array}$ & 9 & Blood & Healthy & Blood donors & $\begin{array}{l}\text { Europe 2. Europe } 3 \\
\text { and Europe } 4\end{array}$ & [26] \\
\hline & $\begin{array}{l}2017- \\
2018\end{array}$ & $8 / 1967$ & $\begin{array}{l}\text { Blood / } \\
\text { Urine }\end{array}$ & $\begin{array}{l}\text { Neuroinvasive diseases / Fever } \\
\text { / Arthralgia / Myalgia }\end{array}$ & Patients with suspected arboviral infection & Europe 2 & {$[27]$} \\
\hline \multirow[t]{2}{*}{ Croatia } & 2013 & $3 / 95$ & Blood & Meningoencephalitis & Meningoencephalitis patients & $?$ & [29] \\
\hline & 2018 & $3 / 178$ & $\begin{array}{l}\text { Blood / } \\
\text { Urine }\end{array}$ & Neuroinvasive diseases & Neuroinvasive cohort & Europe 2 & [30] \\
\hline Germany & 2016 & 1 & Blood & Healthy & Blood donors & Europe 3 & [34] \\
\hline Netherlands & 2018 & $7 / 12040$ & Blood & Healthy & Blood donors & Europe 3 & [36] \\
\hline France & 2016 & $1 / 166$ & CSF & Idiopathic facial paralysis & $\begin{array}{l}\text { Patients with infection and/or neurological } \\
\text { signs }\end{array}$ & Africa 2 & [31] \\
\hline \multirow[t]{2}{*}{ Austria } & 2017 & $6 / 12047$ & Blood & Healthy & Blood donors & Europe 2 & [32] \\
\hline & 2018 & $\begin{array}{l}18 / \\
31598\end{array}$ & Blood & Healthy / Rash & Blood donors & $\begin{array}{l}\text { Europe } 2 \text { and } \\
\text { Africa } 3\end{array}$ & [33] \\
\hline Hungary & 2018 & 1 & Blood & Aseptic meningitis & Clinical case & Europe 2 & {$[28$} \\
\hline
\end{tabular}

This table summarizes acute human cases of USUV infection described in the literature and the viral strains involved CAR Central African Republic 
associated with different lineages. However, it is interesting to note that the majority of patients developing neurological symptoms are related to the EU2 strain, which is actively circulating in several European countries including Italy. It has been reported in the literature that among 24 patients presenting neurological symptoms, 13 cases were infected with EU2 [20, 27, 28, 30], one with AF2 [31], and one with EU1 [19], while for the other cases the strains involved were not characterized. USUV isolates have also been identified in asymptomatic infected patients or infected patients with mild clinical signs, such as AF3 [18, 33], EU1 [24], EU2 [26, 32, 33], EU3 [26, 34, 36], and EU4 [26]. Complete genome sequencing and phylogenetic analyses of African and European lineages have shown genetic diversity among all USUV strains analyzed [40]. The pathogenicity of USUV strains currently circulating in Europe still remains to be investigated in order to understand the epidemiology and evolution of USUV. It has been well described that the neuroinvasive potential of many flaviviruses is straindependent [41, 42]. This is the case for WNV which shares a lot of similarities with USUV [43]. However, little is known with respect to the neurovirulence of USUV lineages, and it could be hypothesized that the lineages currently circulating in Europe differ according to their virulence profiles.

The aim of this present study was to characterize the viral neurotropism and neuropathogenicity of six USUV strains (EU1, EU2, EU3, EU5, AF2, and AF3 lineages) currently circulating in Europe, using a suckling immunocompetent mouse model and both murine and human brain cells. Despite the fact that all USUV strains were neurotropic and lethal in vivo, we observed different rates of replication, cytokine induction, and mortality between the different lineages. The EU2 isolate was the most virulent, with $100 \%$ mortality in vivo and induction of symptoms comparable to epileptic seizures. These symptoms were not observed among the other strains. In vitro, we found that all isolates infected cerebral cells types, such as murine neurons and microglia, human pericytes, brain endothelial cells, and astrocytes. However, in vitro infection showed that USUV isolates gave rise to different growth dynamics. Interestingly, the EU2 lineage exhibited the highest cell infection level, with both higher and more persistent replication rates, while also inducing an atypical cytopathic effect (CPE) characterized by dark cell clusters that detached from the cell mat.

\section{Materials and methods} USUV strains and cellular infection

Europe 1 strain (Vienna 2001-blackbird) was from INIA Madrid (Spain); Europe 2 (TE20421/Italy/2017 and TE18982/Italy/2017) was provided from Istituto
Zooprofilattico Sperimentale, Emilia Romagna (Italy); Europe 3 (USUV-HautRhin7315/France/2015), Africa 2 (Rhône 2705/France/2015), and Africa 3 (USUV-HauteVienne4997/France/2018) strains were from ANSES (National Agency for Food, Environmental and Occupational Health Safety, France); and the Europe 5 (BNI$507 / 2016 /$ Germany) strain was coming from Bernhard Nocht Institute for Tropical Medicine, Hamburg (Germany) (Table 2). The virus lineages were amplified no more than four times on Vero cells (ATCC CCL-81). Viral stocks were prepared by infecting $80 \%$ confluent Vero cells, and cellular supernatants were collected 5 to 7 days after infection. Viral titers were determined by TCID 50/ml, which were calculated using the SpearmanKärber method [44]. For infections, cells at sub confluence were rinsed once with PBS, and USUV was added in a small volume of medium for $2 \mathrm{~h}$ at $37^{\circ} \mathrm{C}$ with constant agitation prior to removing the inoculum.

\section{Mouse experiments}

Six-day-old neonatal Swiss mice (Janvier Laboratories, Saint-Berthevin Cedex, France) were inoculated intraperitoneally with $10^{3}$ TCID50/mice of USUV ( $n=10$ to 12 mice per group). Cervical dislocation was used to euthanize mice at the end of the experiment or if mice presented general deterioration in their condition. Tissues were snap frozen in liquid nitrogen for the determination of the viral burden or fixed in $4 \%$ paraformaldehyde (PFA) and cut using a microtome (3$\mu \mathrm{m}$ sections) at the RHEM facilities (Montpellier) for histological analysis.

\section{Histology and immunostaining}

Briefly, samples were collected and fixed for $24 \mathrm{~h}$ in neutral buffered formalin $10 \%$ and embedded in paraffin. Tissues were cut into $3-\mu \mathrm{m}$-thick sections, mounted on slides, then dried at $37^{\circ} \mathrm{C}$ overnight, and stained as previously described [45]. The slides were incubated at $37^{\circ} \mathrm{C}$ for $60 \mathrm{~min}$ with a rat anti-CD45 antibody (140451, Bioscience) or a rabbit anti-Cleaved caspase 3 antibody (9671, Cell signaling). For viral antigen immunostaining, the slides were incubated at $37^{\circ} \mathrm{C}$ for $32 \mathrm{~min}$ with a mouse anti-flavivirus group antigen monoclonal antibody (Millipore, MAB10216). A scanner (Hamamatsu NanoZoomer 2.0-HT) was used to analyze the slides. Staining cells were quantified with the QuPath bioimage analysis software.

\section{Viral quantification for in vivo experiments}

Organs were crushed with zirconia beads (Fastprep apparatus, MP Biomedicals) in $500 \mu \mathrm{L}$ PBS before RNA extraction (RNA RNeasy Mini-Kit, Qiagen). Urine and blood RNA were extracted with the EZ1 DSP virus kit (Qiagen), and viral RNA levels were quantified by a one- 
Table 2 Country, year of isolation, host source, and passage history of the USUV strains used in the study

\begin{tabular}{lllllll}
\hline Lineage & Strains Name & Country of isolation & Year of islolation & Isolation source & Number of passages & Ref/accession number \\
\hline Europe 1 & Vienna-2001-blackbird & Austria & 2001 & Avian & 4 & AY453411.1 \\
Europe 2 & TE20421/Italy/2017 & Italy & 2017 & Avian & 3 & TE20421 \\
Europe 3 & USUV-HautRhin7315 & France & 2015 & Avian & 4 & KX601690 \\
Europe 5 & BNI507/2016/Germany & Germany & 2016 & Avian & 3 & KY113091 \\
Africa 2 & Rhône 2705 & France & 2015 & Avian & 3 & KX601692 \\
Africa 3 & USUV-HauteVienne49777 & France & 2018 & Avian & 4 & AF4997 (MT863562)
\end{tabular}

step quantitative reverse transcriptase PCR assay (RTqPCR) (Light Cycler 480, Roche) as previously described [46]. Viral load was reported as TCID50 equivalents per gram using a standard curve produced using serial 10fold dilutions of USUV with known viral titers.

\section{Cells}

Vero cells (ATCC CCL-81) and immortalized murine microglial cell line BV-2 (generated by Dr. Elisabetta Blasi [47]) were cultured in DMEM medium containing $10 \%$ fetal bovine serum (FBS). C6/36 cells (ATCC CRL1660 ) were grown in RPMI medium with $10 \%$ of FBS. Human pericytes and astrocytes cells (catalog \#1200 and $\# 1830$, ScienCell ${ }^{\mathrm{TM}}$ ) were cultured on poly-L-lysinecoated plates. Human endothelial cells were purchased from ScienCell ${ }^{\mathrm{TM}}$ and cultured on fibronectin-coated plates. Mouse hippocampal neurons (E18) were obtained and plated using standard procedures as previously described [44].

\section{Immunofluorescence assays}

Cells were fixed with $4 \%$ PFA and permeabilized for 5 min at room temperature with $0.1 \%$ Triton X-100. After a blocking step for $30 \mathrm{~min}$ to $1 \mathrm{~h}$ at RT with $2 \%$ bovine serum albumin (BSA), an incubation step with primary and secondary antibodies was performed. Cells were then fixed and incubated during $5 \mathrm{~min}$ with Hoechst (Sigma) and mounted with fluorescent mounting medium (Prolongold, Thermo Fisher). Samples were imaged by the Zeiss SP85 confocal microscope. Infected cells were quantified by counting 10 fields per conditions per experiments ( $\geq 1000$ cells, $n=3$ ).

\section{ELISA (enzyme-linked immunosorbent assay)}

At various days post-infection, ELISA assays for human CCL5, IL6, and CXCL10 were performed in mock- and USUV-infected supernatants from microglia cells and astrocytes cells (R\&D systems). Data were analyzed on a spectrophotometer (Thermo Fisher Scientific). Absorbance was measured at $450 \mathrm{~nm}$. Mean concentrations $(\mathrm{pg} / \mathrm{mL})$ of cytokines were all superior to the detection limits, defined as the mean background value plus two standard deviations (stddev).

\section{RT-qPCR assays}

USUV- or mock-infected cells (microglia and astrocytes) or mouse brain homogenates were harvested in RLT buffer (Qiagen), and RNA was extracted using RNeasy Mini-Kit (Qiagen). cDNA was synthesized (Omniscript reverse transcriptase, Life Technologies), and then analysis was done with a LC480 real-time PCR instrument (Roche). HPRT gene was used to normalize gene expression.

\section{Brdu test}

Cell proliferation was evaluated by enclosing 5000 cells in 96-well plates. Astrocytes cells were infected with six USUV lineages at a multiplicity of infection (MOI) 0.1. At $7 \mathrm{dpi}$, a bromodeoxyuridine ELISA test was performed (Calbiochem BrDU cell proliferation test) according to the manufacturer's instructions. Absorbance was measured using a spectrophotometer at $450 \mathrm{~nm}$ (TECAN).

\section{MTT test}

Cellular apoptosis was evaluated by enclosing 5000 cells in 96-well plates. Astrocytes cells were infected with six USUV lineages at a MOI 0.1. At $4 \mathrm{dpi}$, the test was performed according to the manufacturer's instructions (Calbiochem, 3-(4,5-dimethyl-2-thiazolyl)-2,5-diphenyl2H-tetrazolium Bromide, Thiazole Blue, MTT - CAS 298-93-1). Absorbance at $570 \mathrm{~nm}$ was measured using a plate reader.

\section{In vitro blood-brain barrier (BBB) model}

Briefly, the in vitro human $\mathrm{BBB}$ models consist in CD34 ${ }^{+}$blood cord-derived endothelial cells (CD34 ${ }^{+}$-EC) that have been differentiated and cultured in transwell filters (Costar) on top of bovine pericytes [48]. Medium was changed every 2 days. Lucifer Yellow (LY; $20 \mu \mathrm{M}$; Life Technologies) was used to test the endothelial permeability (Pe) by calculating the concentrationindependent parameter, and the fluorescence was detected at $432 / 538 \mathrm{~nm}[48,49]$. If the barrier is impermeable ( $P e \leq$ to $1 \times 10^{-3} \mathrm{~cm} / \mathrm{min}$ ), this model was infected with USUV at the MOI of 0.1. After $2 \mathrm{~h}$, the inoculum was removed and $500 \mu \mathrm{L}$ of fresh medium was added. The medium was also changed at 4, 7, or $10 \mathrm{dpi}$. 
Transendothelial electrical resistance (TEER) measurements

According to the manufacturer's instructions, the TEER was evaluated with the Epithelial Volt/Ohm Meter EVOM2 (World Precision Instruments, Hertfordshire). Electrodes were equilibrated in media and placed in the upper and lower chambers. Background measurement of a Matrigel-coated insert (with no cells) was subtracted from the reading and the value was multiplied by the growth surface area, to determine the TEER values $\left(\mathrm{Ohms}^{*} \mathrm{~cm}^{2}\right)$.

\section{Determination of neuropathogenicity markers}

Neurovirulence and neuroinvasiveness markers such as predicted $\mathrm{N}$-linked glycosylation sites or the occurrence of certain amino acids described to be associated with increased virulence were determined as described previously [50]. Amino acid sequences of the polyprotein of each viral strain were aligned using MUSCLE (MUltiple Sequence Comparison by Log-Expectation, EMBL-EBI). A percent identity matrix was generated aside with the alignment (Fig. 9a). Some N-linked glycosylation sites as well as specific mutations were highlighted (Fig. 9b).

\section{Statistical analyses}

A least three independent experiments with three replicates were done for each experiment. Student's $t$ test and the Mann-Whitney $\left(" p<0.05,{ }^{* *} p<0.01\right)$ were used to analyze unpaired data with GraphPad Prism software.

\section{Results}

USUV isolates are neurotropic but exhibit different virulence profiles in suckling immunocompetent mice

It remains to be described whether all USUV strains can enter the central nervous system (CNS) and cause similar damage to the brain parenchyma or whether lesions are strain-specific. To better characterize the neurovirulence of USUV isolates, we first evaluated the susceptibility of mice to six different USUV lineages (EU1, EU2, EU3, EU5, AF2, and AF3). These isolates were at low passage numbers in order to avoid accumulation of mutations owing to extensive passaging (Table 2, Fig. 1). There is a limited number of experimental models that enable the study of flavivirus virulence because wild-type adult mice are resistant to infection by many of these viruses, including Dengue virus (DENV), USUV, and Zika virus (ZIKV) [51, 52]. To overcome this problem, it is possible to use transgenic mouse models. Mice lacking the interferon type 1 receptor $\left(\right.$ Ifnar $^{-/-}$) display enhanced susceptibility to infection by flaviviruses [53, 54], and immunocompetent suckling mice are susceptible to viral infection given they have not yet fully developed a functional interferon (IFN) response [51].
To compare and study strain virulence in vivo, neonatal immunocompetent Swiss mice were intraperitoneally (i.p.) infected with different USUV strains at $10^{3}$ tissue culture infectious dose 50\% (TCID50) per mouse. Symptoms and mortality were monitored for 20 days. The EU2 strain exhibited the most virulent phenotype as all mice infected by this strain died 10 days post-infection (dpi), whereas the mortality rates for mice infected by EU5, AF3, EU1, EU3, and AF2 strains were $85 \%, 80 \%, 56 \%, 54 \%$, and $53 \%$, respectively, at $20 \mathrm{dpi}$, the end of the experiment (Fig. 2a). The mean time-to-death was also different between the strains. EU2- and AF2-infected mice died more quickly (8-9 dpi) versus the EU3-, EU5-, and EU1-infected mice (10, 11, and $13 \mathrm{dpi}$, respectively), whereas AF3-infected mice had a delayed time-to-death with an average of 16 dpi (Fig. 2b). Among infected mice, lethargy and inactivity, limb weakness, and paralysis of the hind limbs appeared on average between 4 and $7 \mathrm{dpi}$ for all strains, except for AF3 for which symptoms appeared later (Fig. 2b). The PBS-inoculated control groups exhibited no signs of disease throughout the experiment. It is interesting to note the induction of convulsive seizures in mice infected with the EU2 strain. These were observed at times of behavioral changes after induction of stress (such as cage changing) and were associated with the epileptiform activities of freezing, tremor, and tail erection. These convulsive seizures were not observed following infection by the other strains, even at later times.

We next investigated the viral burden in the blood and brain of infected mice. In the blood, the viral copy number was higher at $6 \mathrm{dpi}$ in EU2- and EU5-infected mice $(p<0.5)$ (Fig. 2c). All strains tested were neuroinvasive given that we detected the virus in the brains of mice infected with all lineages. However, brain viral burden at 6 dpi was lower in EU1-, EU3-, EU5-, AF2-, and AF3infected mice compared to EU2-infected mice $(p<0.01)$ (Fig. 2c). EU2-infected brains also showed the presence of more viral antigen by immunohistochemistry staining compared to the other strains, such as AF3- or EU5infected mice, presenting less viral antigen (Fig. 2d).

Overall, our observations suggest that despite the fact that all strains appear neurotropic and induce neurological impairment in mice, they also have different virulence profiles, particularly the EU2 isolate which appears more pathogenic in this mouse model.

\section{USUV strains differentially induce brain inflammation}

As suggested by previous studies $[15,45,55]$ and clinical signs observed in our infected mice in this study (such as epilepsy, hind-limb paralysis, limb weakness, and lethargy), USUV infects, replicates, and damages the brain, in turn causing functional abnormalities. To better describe the brain infection profile following infection by the different isolates, we performed 


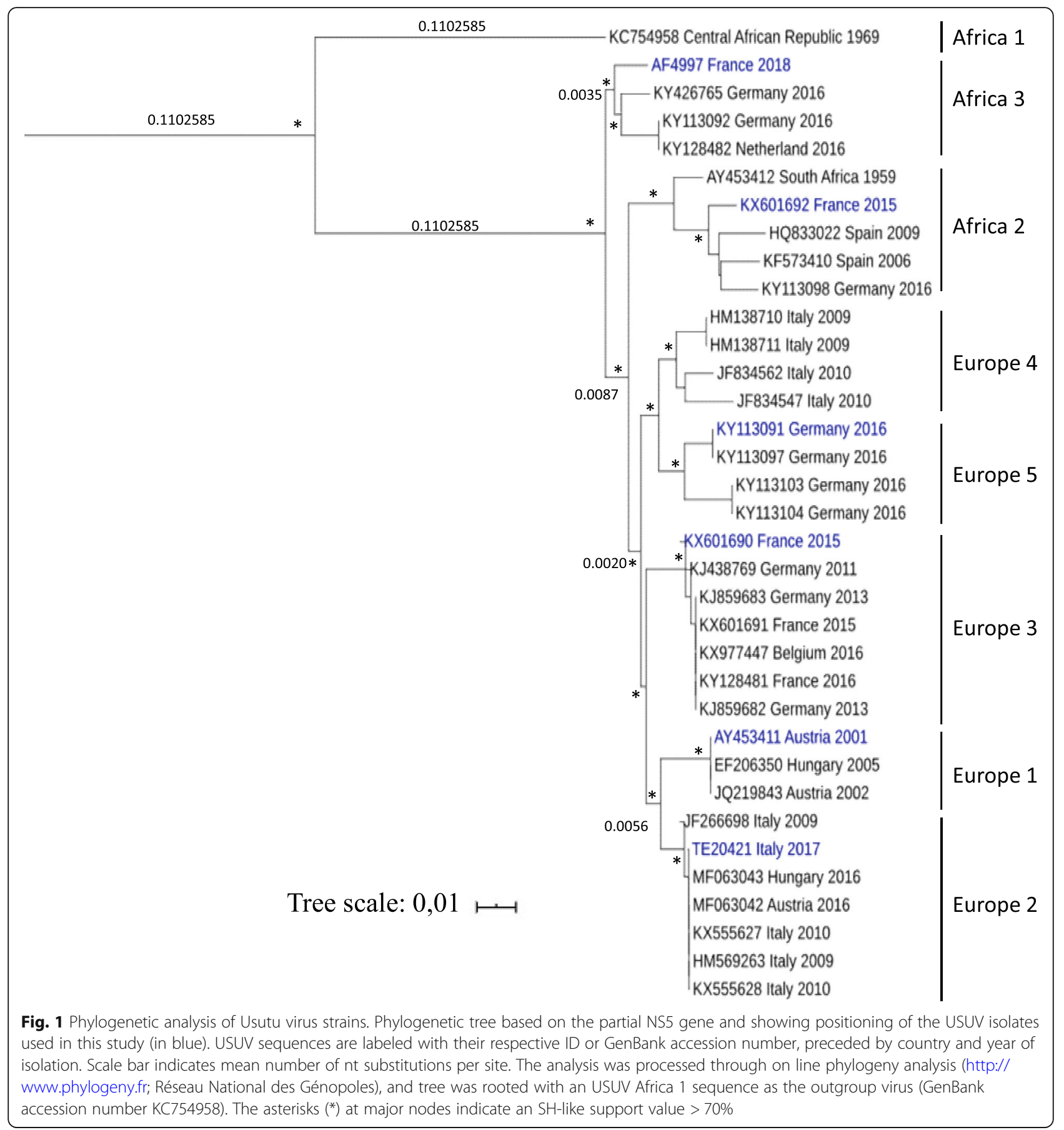

immunohistochemistry in infected brains at $6 \mathrm{dpi}$. Brain sections were stained with an anti-CD45 antibody, which labels all lymphoid cells. We observed USUV-induced recruitment of $\mathrm{CD} 45^{+}$cells for all isolates (Fig. 3a). Cellular infiltration was higher in EU1-, EU2-, and EU5-infected mice compared to the other groups. Caspase-3 staining showed minimal apoptosis, but still more cell death was observed in EU1- and EU2-infected mice (Fig. 3a). To evaluate whether the recruitment of inflammatory cells was correlated with the overexpression of inflammatory cytokines, we analyzed the inflammatory profiles of infected brains at 6 dpi by RT-qPCR (Fig. 3b). We chose markers that have already been associated with viral encephalitis and neurodegenerative diseases, including tumor necrosis factor alpha (TNF $\alpha$ ), interleukin 6 (IL6), and interleukin $1 \beta$ (IL1 $\beta)$. We detected a strong increase in expression of Tnfo, Il6, and Ill $\beta$, but also interferon beta $(\operatorname{Inf} \beta)$ in all mouse USUV-infected brains. Increases 
A

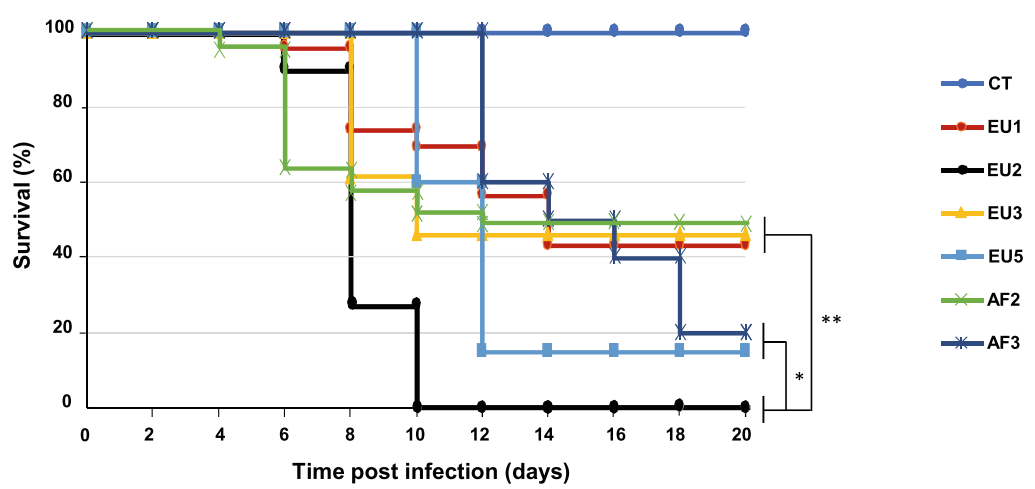

B

\begin{tabular}{|l|c|c|c|c|c|c|}
\hline & \multicolumn{7}{|c|}{ Mean onset date (dpi) } \\
\hline Symptoms & EU1 & EU2 & EU3 & EU5 & AF2 & AF3 \\
\hline Lethargy and inactivity & 6 & 4 & 5 & 5 & 5 & 9 \\
\hline Limb weakness & 6 & 5 & 6 & 5 & 5 & 9 \\
\hline Hind-limb paralysis & 7 & 5 & 6 & 6 & 6 & 10 \\
\hline Weight loss & 8 & 7 & 8 & 7 & 7 & 10 \\
\hline Epilepsy & NO & 6 & NO & NO & NO & NO \\
\hline Moribund and death & 13 & 8 & 10 & 11 & 9 & 16 \\
\hline Percentage of mortality & 56 & 100 & 54 & 85 & 53 & 80 \\
\hline
\end{tabular}

C

Blood

Brain
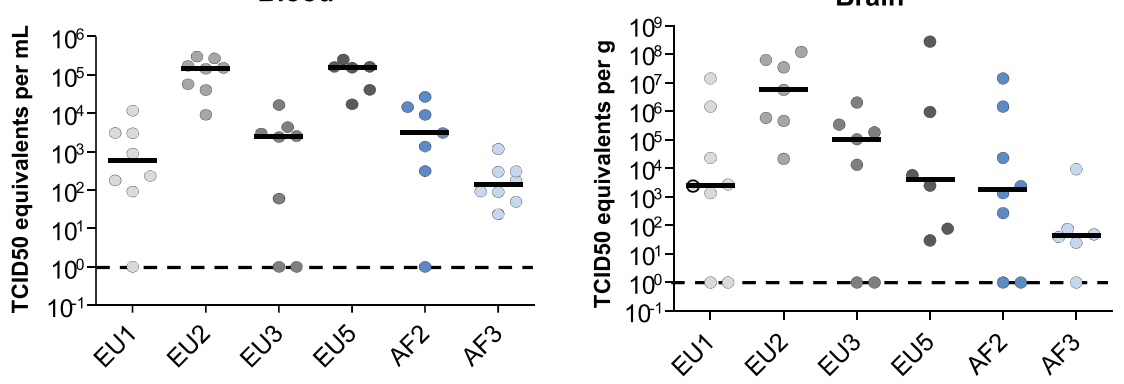

D

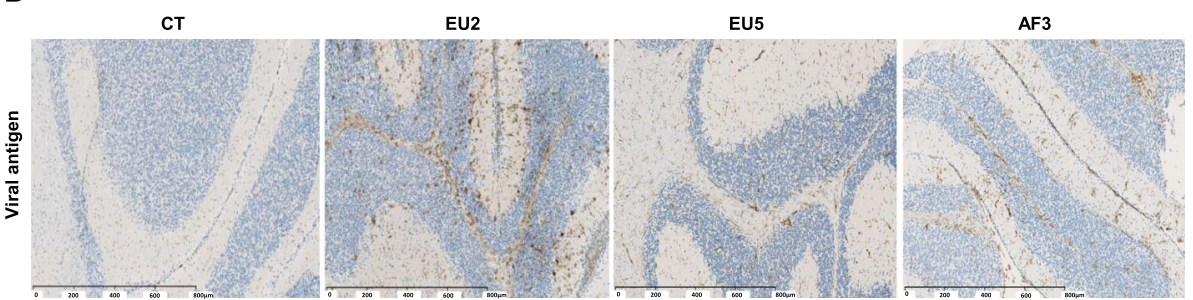

Fig. 2 Clinical signs of USUV infection in suckling immunocompetent mice according to strains. a Survival rates of neonatal Swiss mice (6 days old) intraperitoneally inoculated with $10^{3} \mathrm{TCID50/mouse} \mathrm{of} \mathrm{six} \mathrm{different} \mathrm{USUV} \mathrm{lineages.} \mathrm{CT} \mathrm{=} \mathrm{control} \mathrm{mice.} \mathbf{b}$ Onset date of symptoms in USUV-infected suckling mice. Mice were monitored daily until clinical signs of disease were displayed and then were euthanized. Symptoms appeared at around 5 dpi for all strains excepted for AF3 (9 dpi). Epilepsy is observed only in mice infected by EU2. $n=6$ for each group. $\mathbf{c}$ Viral burden in blood and brain was measured by RT-qPCR assay at $6 \mathrm{dpi}$ and indicated by TCID50 equivalent per $\mathrm{mL}$ or per gram. $\mathbf{d}$ Transverse sections of the brain (cerebellum) of USUV-infected mice at $6 \mathrm{dpi}$ showing the presence of viral antigen after pan-flavivirus staining (associated with luxol blue). ${ }^{*} p<0.05$ and ${ }^{* *} p<0.01$

in expression were generally smaller for African isolates compared to European isolates, except for $I l 1 \beta$ expression with varying expressions between strains.

USUV isolates differentially infect and replicate in primary human astrocytes and induce deleterious effects on cellular proliferation and apoptosis

To better understand the capacity of USUV to infect the brain, we compared USUV isolate virulence in various cell types of the CNS. Firstly, we infected primary human astrocytes with all isolates at a MOI of 0.1. Surprisingly, an atypical CPE was observed at $7 \mathrm{dpi}$ following infection by the EU2 isolate (Fig. 4a). USUV-induced CPE are often characterized by cells rounding up during necrosis, apoptosis, or pyroptosis [56]. Here, CPE induced by EU2 was characterized by dark clusters of cells that detached from the cell mat whereas the other isolates demonstrated typical $\mathrm{CPE}$. In order to determine 
A

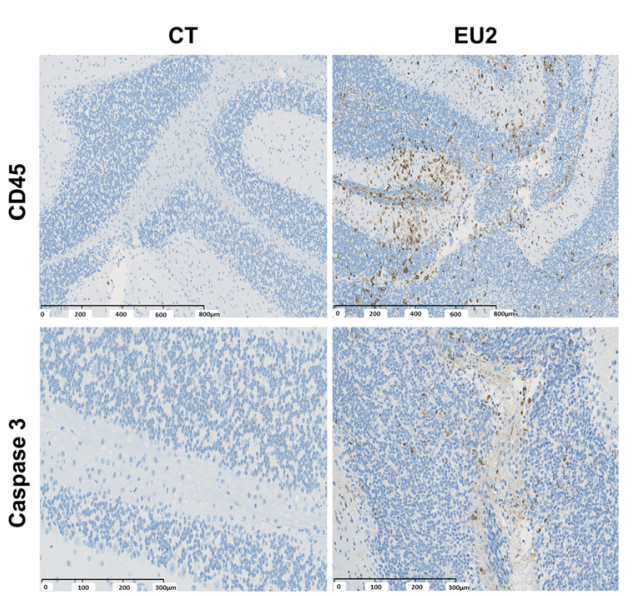

B

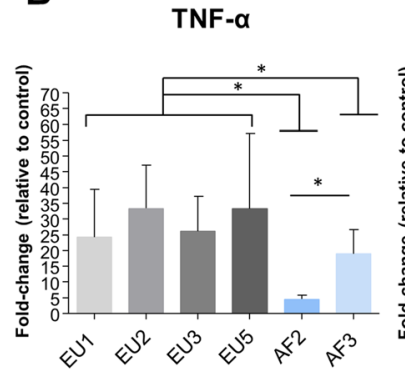

IL6
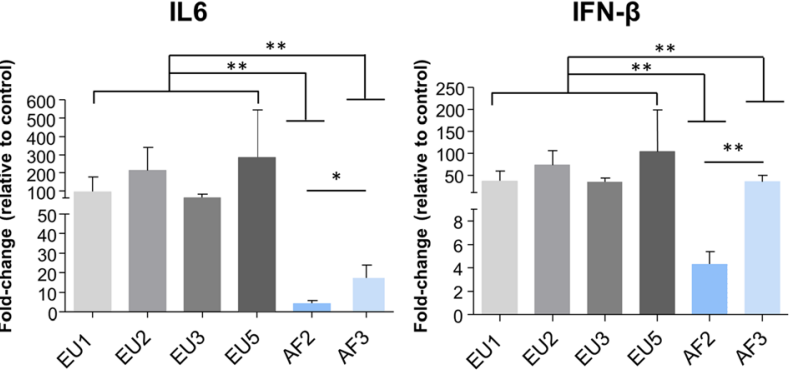
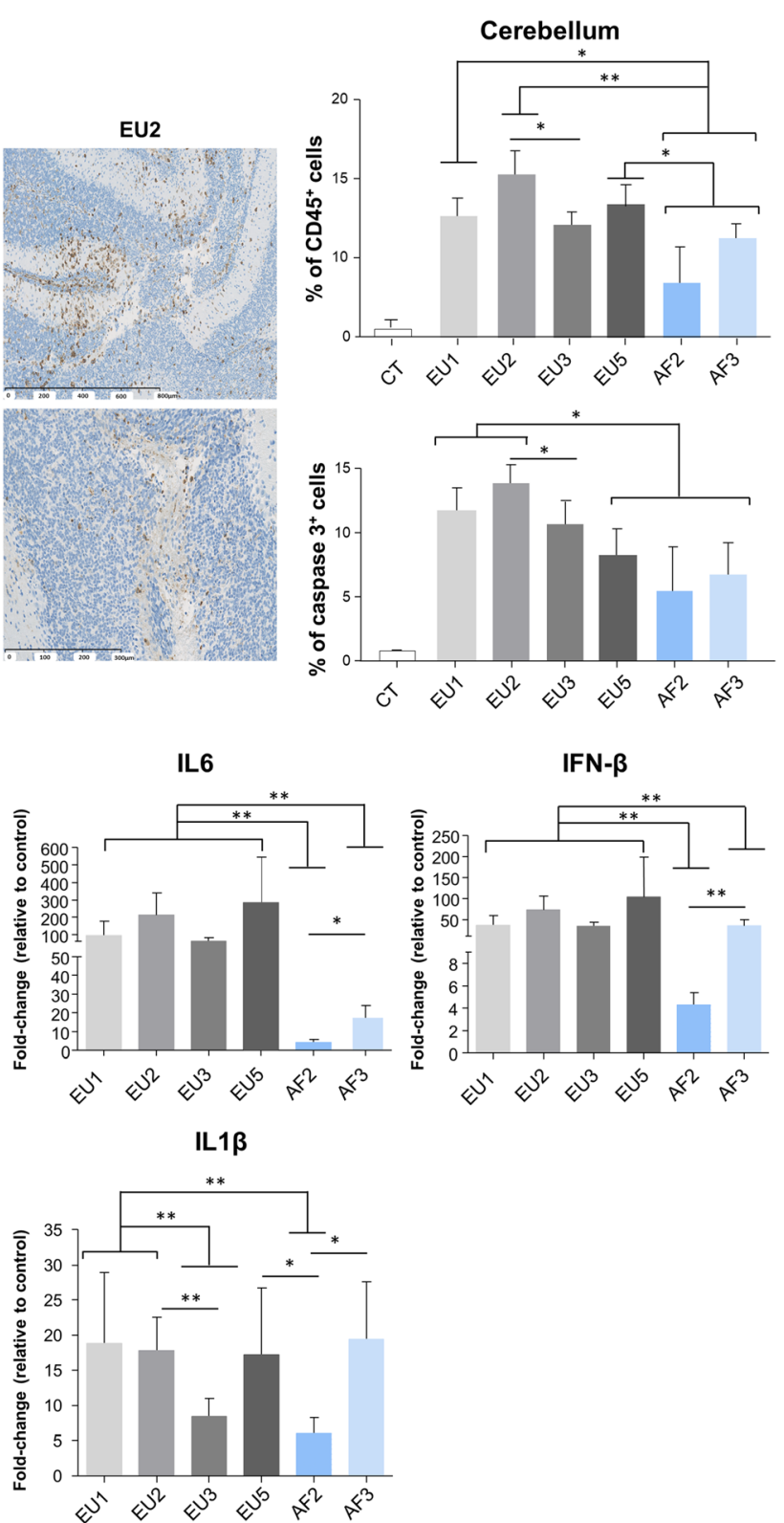

Fig. 3 USUV isolates differentially induce cellular infiltration, apoptosis, and inflammation in the mice brain. a Left panel: Immunohistochemical CD45 staining (associated with luxol blue) showing inflammatory infiltrates in the infected brain (brown staining) at 6 dpi. Some cells present caspase 3 staining after immunohistochemistry. Right panel: Quantification of CD45-positive cells and caspase 3 positive cells in USUV-infected brain compared to CT. $\mathbf{b}$ qRT-PCR analysis of TNFa, IL6, IFN $\beta$, and IL $1 \beta$ mRNA from the brain collected at 6 dpi. Each histogram represents the mean \pm SEM from 6 independent mice normalized to $C T$. ${ }^{*} p<0.05$ and ${ }^{*} p<0.01$

whether this CPE was characteristic of the EU2 lineage, we analyzed another EU2 isolate (TE18982). We observed the same atypical $\mathrm{CPE}$, suggesting that this observation could be lineage-dependent rather than straindependent (Supplemental Figure 1A).

Since the replicative capacity of a virus is considered to be a marker for virulence, we studied the replicative capacity of the different USUV strains in astrocytes. This approach is based on the fact that the most virulent viral strains produce more progeny, which can lead to higher viral densities and therefore greater levels of virulence. Astrocytes infected with the EU1 and EU2 strains released more infectious viral particles at $2 \mathrm{dpi}$ than astrocytes infected with the other strains for which no significant amplification is observed (Fig. 4a). At later times of infection (until $7 \mathrm{dpi}$ ), EU2 produced higher titers than the other strains as the production of viral particles further increased while decreasing for all the other strains (Fig. 4a). 
A

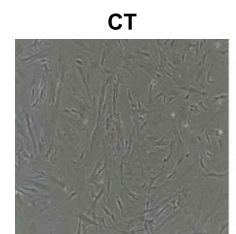

EU1
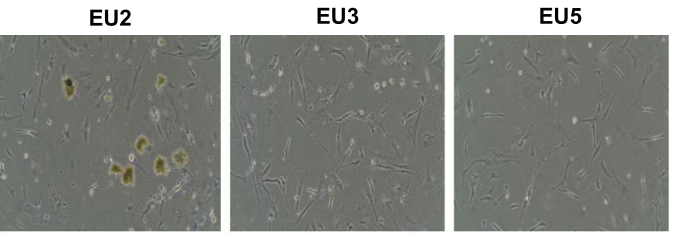

CT

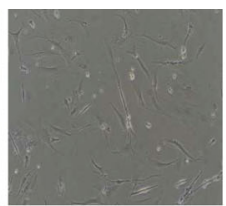

AF3
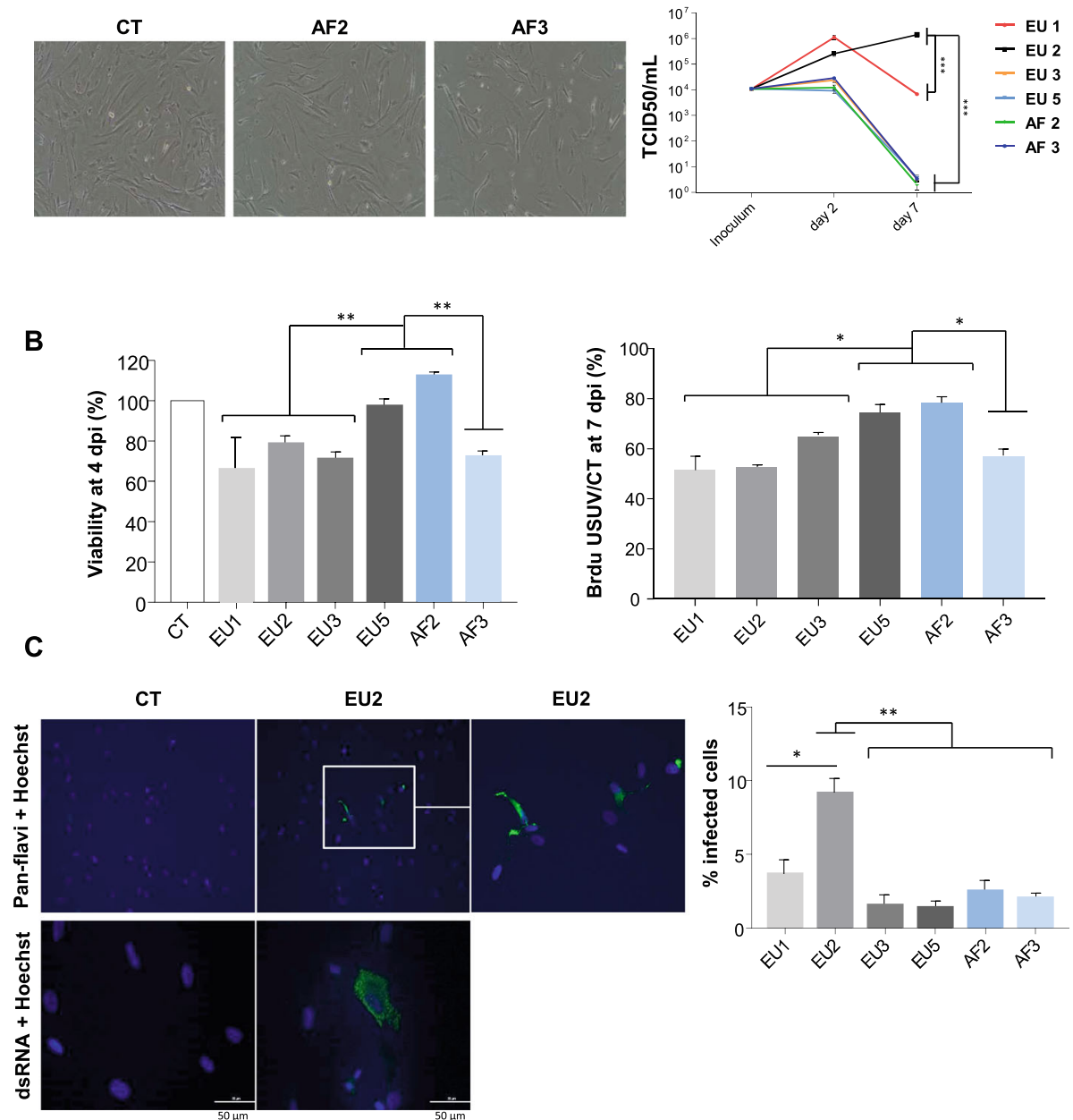

EU2
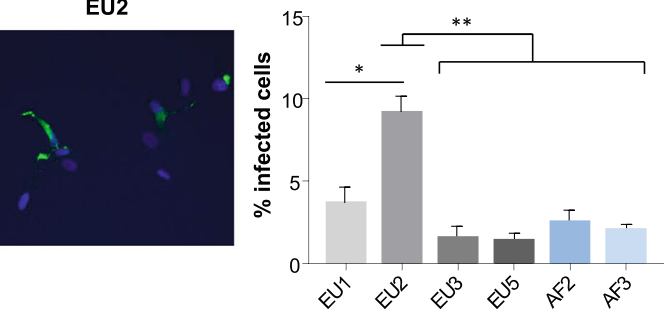

Fig. 4 Comparative virulence between USUV strains in primary human astrocytes. Primary human astrocytes were infected with the six lineages of USUV at a MOI of 0.1. a Left panel. Bright light images of CT- and USUV-infected astrocytes showing at 7 dpi an atypical CPE which appeared specifically with the EU2 strain. This CPE is characterized by dark clustered cells that detach from the cell mat. Right panel: Supernatants from infected cells were collected at 2 and $7 \mathrm{dpi}$ and subjected to TCID50 measurement on Vero cells. EU2 strain replicates longer in astrocytes. Results are expressed as mean \pm SEM of 3 independent experiments. b Apoptosis ( 4 dpi) and cellular proliferation ( 7 dpi) measured by MTT and BrDU are affected by USUV infection. c Left panel. Mock and EU2 USUV-infected cells were fixed at $2 \mathrm{dpi}$ and labeled with the pan-flavivirus antibody (in green) or double-stranded RNA antibody (in green) by indirect immunofluorescence. Nuclei are labeled with Hoechst (in blue) immunofluorescence ( $\times 20$ and $\times 40$ ). The white square represents a zoom on infected cells. Scale bar $=50 \mu \mathrm{m}$. Right panel: Quantification of infected cells at 2 dpi (using panflavivirus antibody) showing more infected cells with the EU2 strain. For all experiments, $n=3$ independent triplicates. ${ }^{*} p<0.05$ and ${ }^{* *} p<0.01$

A similar trend was observed for the other EU2 strain (Supplemental Figure 1B). This is a surprising result because even with CPE the production of viral particles continued to increase over time, suggesting that the virus is persistent and the remaining cells produce a significant amount of infectious viral particles.
To measure the viability of infected astrocytes we performed MTT (3-(4,5-dimethylthiazol-2-yl)-2,5-diphenyltetrazolium bromide) tests at 4 dpi. Results showed more cell death following infection by EU1, EU2, EU3, and AF3 strains compared to EU5 and AF2 strains (Fig. 4b). Given bright-field microscope images of USUV-infected 
astrocytes seemed to indicate a defect in cellular proliferation, we next explored whether cell division was affected by USUV infection. Astrocytes infected or not by USUV strains were incubated in the presence of the nucleotide analog BrdU and then quantified at $7 \mathrm{dpi}$ by ELISA (Fig. 4b). Compared to non-infected cells, all USUV-infected astrocytes showed a decrease in proliferation at $7 \mathrm{dpi}$ which is however less important for EU5 and AF2 isolates. Pan-flavivirus immunofluorescence staining showed very few positive cells but we clearly observed more infected cells after EU2 infection (Fig. 4c). The pattern of antigen staining was characteristic of antigen distribution in the endoplasmic reticulum, a classical site for flavivirus replication (Fig. 4c). Doublestranded RNA staining also indicated an efficient EU2 replication in astrocytes (Fig. 4c). Altogether, these results suggest that the EU2 strain targets primary human astrocytes more efficiently than the other USUV lineages and replicates for longer time.

\section{Variation of chemokine and cytokine secretion, and gene expression levels in primary human astrocytes between different USUV isolates}

Astrocytes, along with microglia, are the predominant source of cytokines and chemokines of CNS resident cells, and thus may act as important processors of neuroinflammation and neurodegeneration [57]. Astrocytes are key players in the inflammatory response during neural infections caused by flavivirus [58, 59]. Consequently, we investigated the mechanisms of induction of the inflammatory signaling elicited by the different USUV isolates in these cells. We first analyzed the modulation of expression of several genes involved in pro-inflammatory cytokine release. We collected mRNAs from USUV- or control-infected human astrocytes at 2 dpi and we performed RT-qPCR to quantify gene transcript levels of selected cytokines (TNFa, CXCL10, CCL5, and IL6) (Fig. 5a). We are interested in these cytokines because innate immunity is generally required for clearance of viral infection, and when clearance is ineffective, excessive cytokine release can occur. This can be detrimental and associated with adverse effects, such as CNS disorders. Thus, the main risk during neuroinvasive viral infection is the dispersion of the virus in the CNS, causing induction of inflammatory responses and destruction of neuronal cells. At $2 \mathrm{dpi}$, we observed a strong upregulation of cytokine mRNA in infected human astrocytes, mainly for the EU1, EU2, and AF3 isolates (Fig. 5a). In parallel, we used enzyme-linked immunosorbent assay (ELISA) to investigate the secretion of CXCL10, CCL5, and IL6 chemokines/cytokines into the culture medium of USUV- and control-infected astrocytes (Fig. 5b). The amount of soluble CXCL10, CCL5, and IL6 was increased in the supernatant of infected astrocytes at $2 \mathrm{dpi}$, but it varies depending on the isolates used for infection similarly to the results obtained by RT-qPCR (Fig. 5b). Increased expression of CCL5 and CXCL10 could enhance recruitment and activation of immune cells and resident neuronal cells at the site of infection, thereby promoting the clearance of free virus as well as of infected cells in the CNS. Indeed, CCL5 has been reported to have both neuroprotective [60] and direct antiviral activities [61]. Moreover, during the inflammatory response, astrocytes may influence the balance between host protection and neurotoxicity. Considering this, we next investigated the antiviral response. We analyzed the effects of USUV strains on the mRNA level of Ifn $\beta$ and several cellular pattern recognition receptors (PRRs), as well as some effectors involved in their signaling pathway, including interferon regulatory factor 3 (IRF3) and myeloid differentiation primary response 88 (MYD88). We observed increased expressions of retinoic acid-inducible gene I (RIG-I), melanoma differentiation-associated antigen 5 (MDA5), and tolllike receptor 3 (TLR3), known to be activated by doublestranded viral RNA during viral replication and involved in IFN $\beta$ induction [62]. These genes all exhibited USUV strain-dependent expression levels. We did not observe a significant increase in toll-like receptor 7 (TLR7) expression (Fig. 5c). In the literature, PRR expression levels generally increase in concert with ascending responses to viral infection, and suchlike increases are considered to reflect pathway activation [62]. Accumulation of these RNA sensors was accompanied by upregulated mRNA expression levels of IFN signaling pathway components, such as IFN $\beta$ itself, but also MYD88 and to a lower extent IRF3 (Fig. 5c).

Altogether, the gene induction profiles were heterogeneous between the strains. These results suggest that USUV isolates differentially affect cytokine/chemokine production and antiviral responses in primary astrocytes.

\section{USUV strains differentially infect and replicate in microglial cells}

Microglia represents the resident immune cells of the CNS. During brain infection, they have a critical role in host defense against invading viruses. We previously described that USUV efficiently infects microglia ex vivo in organotypic murine brain slices [45] and the hippocampal area of USUV-infected mice [56]. To determine if USUV isolates can infect microglial cells in vitro, we infected the immortalized murine microglial cell line BV-2 at an MOI of 0.1 [63]. Comparable to our results obtained with astrocytes, we observed an atypical CPE at 5 dpi in microglia infected with the EU2 lineage (Fig. 6a) but not with the other lineages, even at later times (Supplemental Figure 2A). This suggested that this atypical $\mathrm{CPE}$ is not a specific feature of infected astrocytes. At 5 

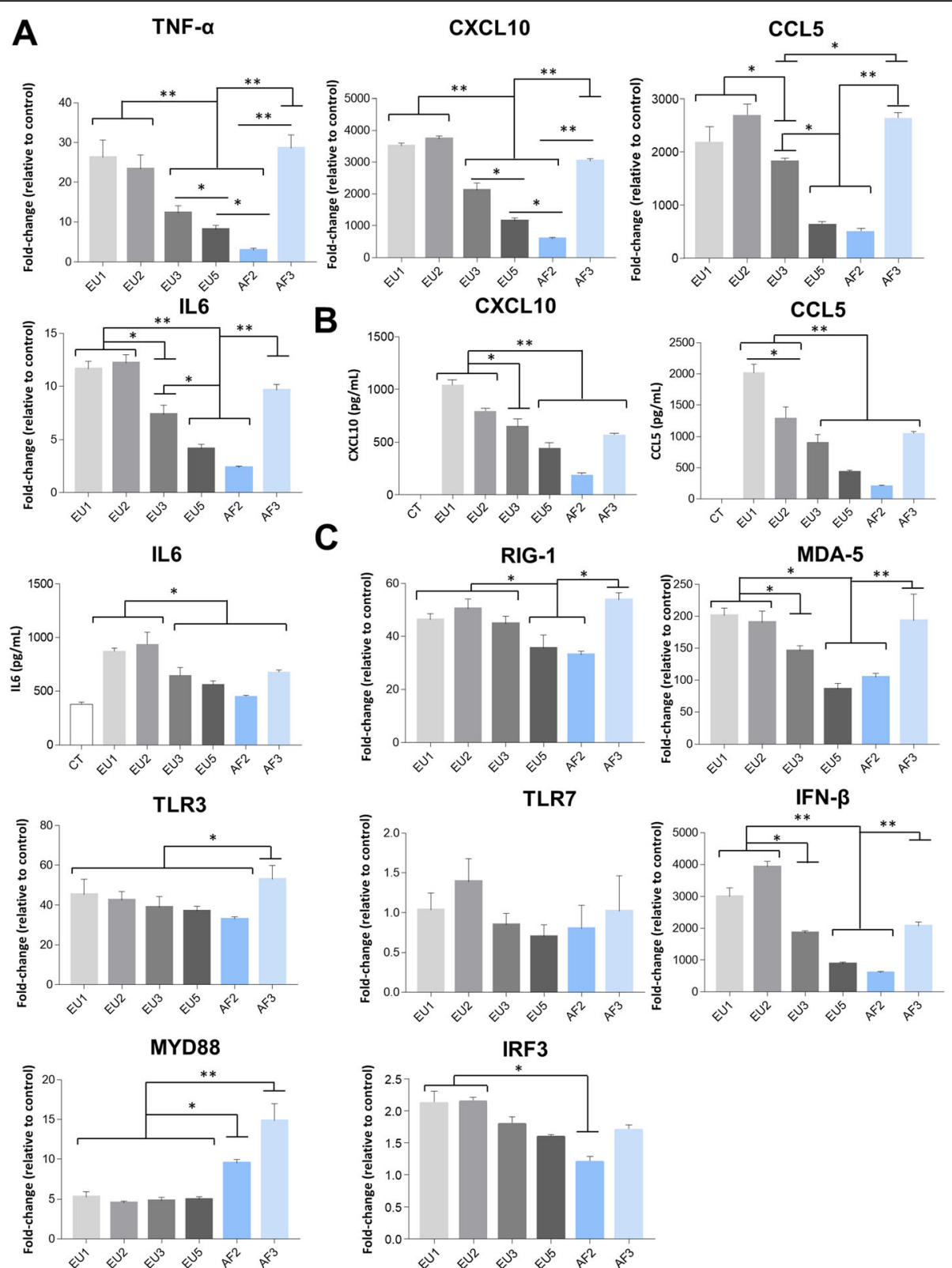

Fig. 5 Infection of astrocytes by USUV strains leads to different profiles in the secretion and expression of pro-inflammatory cytokines. a qRT-PCR analysis of TNFa, CXCL10, CCL5, and IL6 mRNA collected at 2 dpi from human astrocytes cells infected or not by USUV. Results are expressed as means of the fold regulation. $\mathbf{b}$ ELISA analyses of CXCL10, CCL5, and IL6 (pg/mL) at 2 dpi. Each histogram represents the mean \pm SEM from 3 independent experiments. c qRT-PCR analysis of RIG-1, MDA-5, TLR3, TLR7, IFN $\beta$, MYD88, and IRF3 mRNA collected at 2 dpi from human infected astrocytes. Results are expressed as means of the fold regulation normalized to CT (3 independent triplicates). ${ }^{*} p<0.05$ and ${ }^{* *} p<0.01$

dpi, viral titer increase for the EU2 lineage while it decreased for all other isolates (Fig. 6a). Moreover, we detected by pan-flavivirus immunofluorescence staining that approximately $50 \%$ of cells were EU2-infected, $23 \%$ were EU1-infected, and less than $10 \%$ were infected by the other strains at 2 dpi (Fig. $6 \mathrm{~b}$ ).

We then investigated the effect of USUV infection on the mRNA expression of key pro-inflammatory cytokines. To compare pro-inflammatory cytokine gene induction between the several isolates in microglia, we collected mRNAs at $2 \mathrm{dpi}$ and performed RT-qPCR to quantify gene transcript levels of Tnfo, Cxcl10, Ccl5, Il6, and $\operatorname{Inf} \beta$. We observed a strong upregulation of these cytokine mRNAs, with the exception of $\operatorname{Tnf} \alpha$, primarily in EU2- and AF3-infected microglia (Fig. 6c). These data highlight the induction of cytokine signaling by USUV in microglia, particularly by the EU2 and AF3 isolates. This was unexpected given that at $2 \mathrm{dpi}$ the AF3 strain 

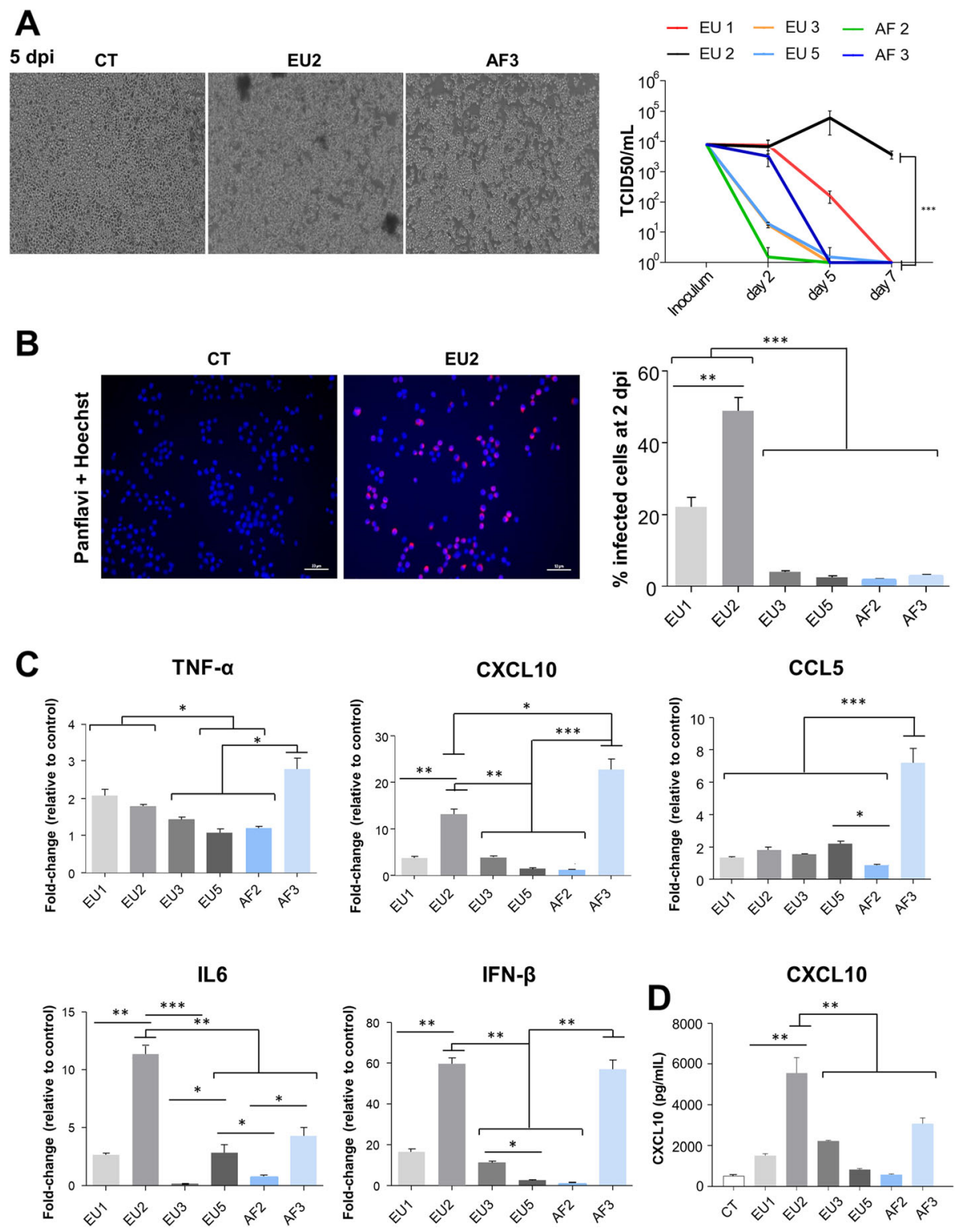

Fig. 6 USUV strains replicate differentially in murine microglia and EU2 strains persist longer. Murine microglia were infected with USUV strains at a $\mathrm{MOI}$ of 0.1. a Left panel: Bright light images of control and USUV-infected microglia at $5 \mathrm{dpi}$. We observe an atypical CPE- in EU2-infected cells. Right panel: Supernatants from infected cells (MOI 0.1) were collected at 2, 5, and $7 \mathrm{dpi}$, and subjected to TCID50 measurement. Viral production in USUV-infected microglia shows difference in terms of replication and persistence between strains, with greater virulence for EU2. b Left panel: USUV-infected cells were fixed at $2 \mathrm{dpi}$ and labeled with the pan-flavivirus antibody (in red) as showed for EU2 strain. Scale bar $=50 \mu \mathrm{m}$. The corresponding quantification is indicated on the right panel ( $n=3$ independent experiments). c RT-qPCR analysis of TNFa, CXCL10, CCL5, IL6, and IFN $\beta$ of mRNA collected at 2 dpi from infected and non-infected (CT) microglial cells. $\mathbf{d}$ Analyses of CXCL10 by ELISA in the supernatants of CT- or USUV-infected microglia at 2 dpi. Results are expressed as mean \pm SEM. ${ }^{*} p<0.05,{ }^{* *} p<0.01$, and ${ }^{* * *} p<0.001$

infected a very small percentage of cells (3\%, Fig. 6b). On the other hand, the AF3 strain ultimately induced efficient replication and a strong inflammatory response, suggesting that the few infected cells present produced a substantial amount of infectious viral particles. CXCL10 protein secretion measured by ELISA was also significantly increased in microglia infected by both EU2 and
AF3 to a lower extent in comparison to the control and other strains (Fig. 6d).

Our results provide evidence that USUV isolates differentially infect and replicate in murine microglial cells. Microglia appear to be more permissive to the EU2 isolate, which also persists longer in this cell type as we already observed in astrocytes. 


\section{All USUV lineages infect pericytes, neurons, and brain endothelial cells, but the EU2 isolate appears more virulent}

Next, we compared the replication of the six circulating USUV strains in other CNS cell types: neurons, pericytes, and brain endothelial cells. Brain endothelial cells are highly specialized cells and form the BBB isolating the CNS parenchyma from the blood. The BBB regulates the flow of solutes, cells, and pathogens [64]. Infection and/or disruption of this barrier might be a key event preceding viral invasion. Pericytes are present on the abluminal surface of brain microvessels, and they have a regulatory effect on $\mathrm{BBB}$ formation and permeability [65]. Although USUV is currently described as a neurotropic virus and we previously reported that it can effectively replicate in murine neurons, the relative ability of USUV to replicate in cells of the $\mathrm{BBB}$, such as pericytes and brain endothelial cells, is unknown [56]. Similar to our results obtained with astrocytes and microglia, the EU2 strain induced an atypical CPE both in neurons (4 dpi) and in brain endothelial cells (6 dpi) (Fig. 7a, c; Supplemental Figures 2B and 3B). Pericytes on the contrary did not demonstrate any CPE following infection by any of the strains ( $4 \mathrm{dpi}$ ) (Fig. 7b, Supplemental Figure 3A). Moreover, it is noteworthy that neuronal damage was observed at $4 \mathrm{dpi}$, showing principally neurite destruction in EU1, EU2, EU3, and AF3-infected neurons (Fig. 7a, Supplemental Figure 2B). Productive USUV replication in neurons and pericytes was observed for all strains (Fig. 7a, b). Viral production in murine neurons and in human pericytes at $4 \mathrm{dpi}$ was higher for the European strains, especially the EU2 isolate (Fig. 7a, b). In human brain endothelial cells, we showed that the EU2 strain replicated strongly and was persistent over time (Fig. 7c). Indeed, the viral titer was very comparable between the different lineages at $2 \mathrm{dpi}$, but at $6 \mathrm{dpi}$ the quantity of EU2 viral particles increased, while it decreased over time from $4 \mathrm{dpi}$ for EU1 and from 2 dpi for the other isolates.

Altogether, our results show that neurons, pericytes, and brain endothelial cells are all permissive to infection by the different USUV strains, but only the EU2 isolate appears again be persistent in these cell types.

\section{USUV EU2 and AF3 infect and replicate in human brain- like endothelial cells (hBLEC) without perturbation of endothelial integrity}

The BBB is very effective in protecting the brain from viruses circulating in the blood. However, neuroinvasive viruses have developed a variety of mechanisms to pass through the $\mathrm{BBB}$ and reach the CNS. Several arboviruses, such as WNV and JEV, lead to endothelial integrity impairment and inflammatory molecule production that can disrupt $\mathrm{BBB}$ integrity and in turn allow access of the virus to the CNS [66-68]. In this study, we used a human in vitro BBB model which recapitulates the essential characteristics of the endothelial barrier. To acquire BBB characteristics, human $\mathrm{CD}_{3}{ }^{+}$cord blood-derived hematopoietic stem cells were cultivated on culture inserts, in co-culture with pericytes for 6-7 days (Fig. 8a). These hBLEC can form tight junctions and express specific transporters [48] which can allow the study of drug or cell passage through the BBB [69, 70]. We have previously shown that USUV AF2 can replicate in hBLEC and cross the BBB without barrier breakdown [45]. Since replication in brain endothelial cells is sufficient to allow viral transport through BBB, we investigated whether both EU2 (particularly virulent) and AF3 (less virulent) strains could infect and disrupt integrity of the $\mathrm{BBB}$ in vitro. Following, hBLEC were infected by USUV on the apical side at an MOI of 0.1. Supernatants were collected at 4, 7, and $10 \mathrm{dpi}$ from the apical (equivalent to blood vessel lumens side) and basolateral (CNS parenchymal side) compartments, and cells were fixed to analyze localization of tight junction proteins, regulating BBB integrity. Thus, endothelial permeability coefficient $(\mathrm{Pe})$ consisting to evaluate the clearance principle of Lucifer Yellow (LY) and transendothelial electrical resistance (TEER) were also measured. Figure $8 \mathrm{~b}$ shows viral titers in apical and basolateral compartments at $4 \mathrm{dpi}$ (corresponding to the production between 0 and 4 days), $7 \mathrm{dpi}$ (production between 4 and 7 days), and $10 \mathrm{dpi}$ (production between 7 and 10 days). For the EU2 strain, weak viral production was detected at 4 and 7 dpi in the basolateral compartment, but production then increased at $10 \mathrm{dpi}$. On the other hand, in the apical compartment, the viral production was high at $4 \mathrm{dpi}$ and decreased at $7 \mathrm{dpi}$, and then increased again at $10 \mathrm{dpi}$ (Fig. 8b). These results suggested an overall efficient production. The AF3 isolate presented a different profile, with no efficient production at 4,7 , or $10 \mathrm{dpi}$, in both the apical and basolateral compartments (Fig. 8b). Pe of LY appeared not significantly altered by either EU2 or AF3 strains at $10 \mathrm{dpi}$, both control and infected endothelia displayed permeability coefficients of $\sim 0.8$ $\times 10^{-3} \mathrm{~cm} / \mathrm{min}$, consistent with a "tight" $\mathrm{BBB}$ endothelium (inferior to 1.0) (Fig. 7c). We observed no significant variation in TEER values after infection (Fig. 8c) and the endothelium remained impermeable with no manifestation of architectural disturbance (Fig. 8d).

Our results suggest that despite USUV EU2 being the most virulent strain among the strains tested in this study, EU2 infects the BBB from the luminal side without deleterious effects on BBB integrity.

\section{Genome analysis highlights mutation in NS5 EU2 strains potentially correlated with virulence}

By comparing the differences at protein level, we found that among USUV strains, the amino acid average pairwise identity was between 98.57 and 99.77\% (Fig. 9a). Mutations predicted to influence virulence, 


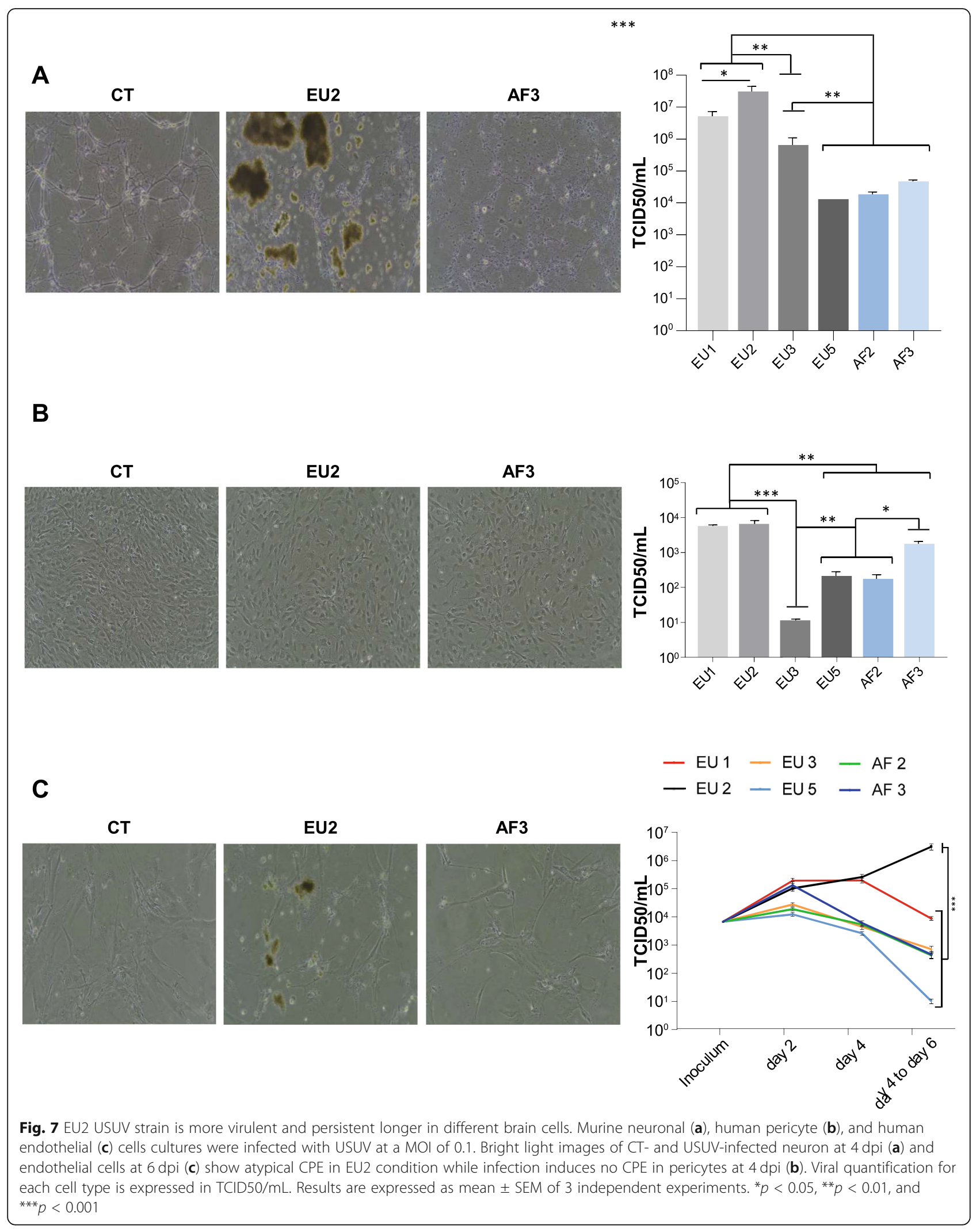



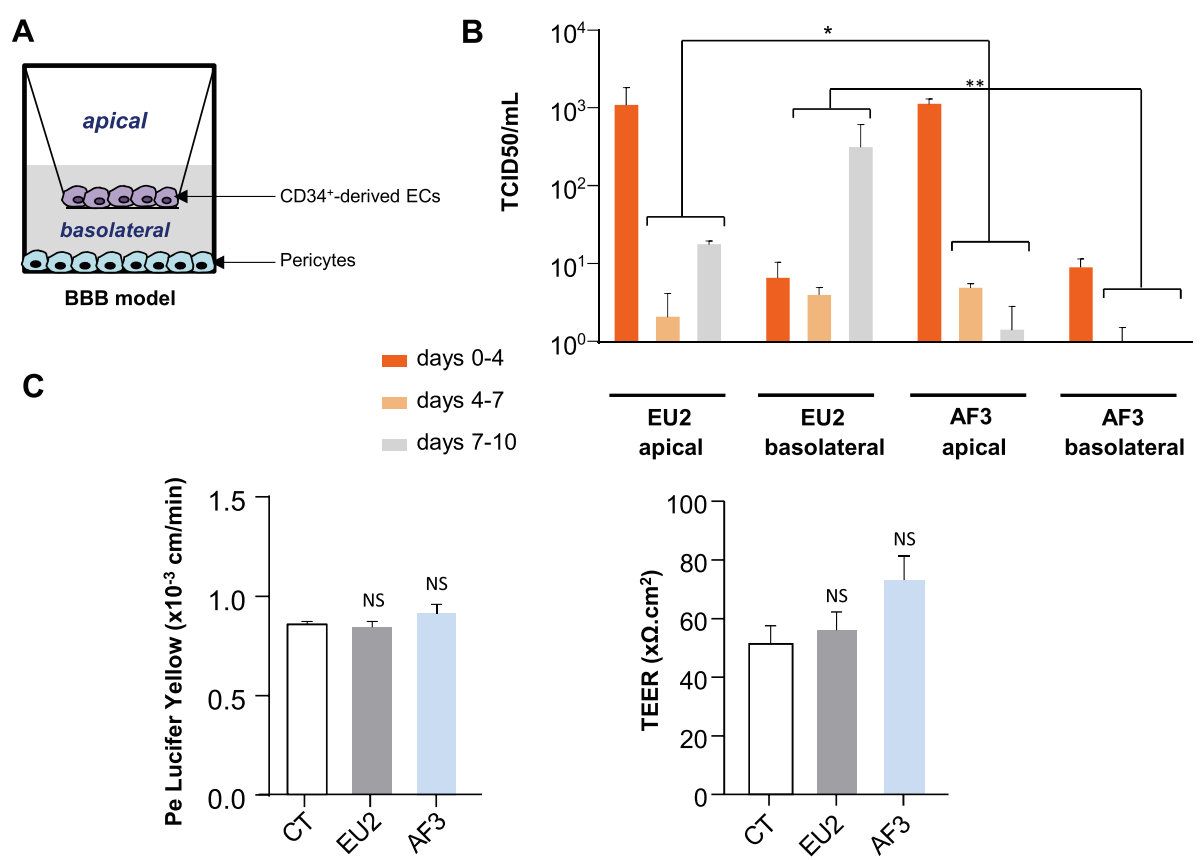

D
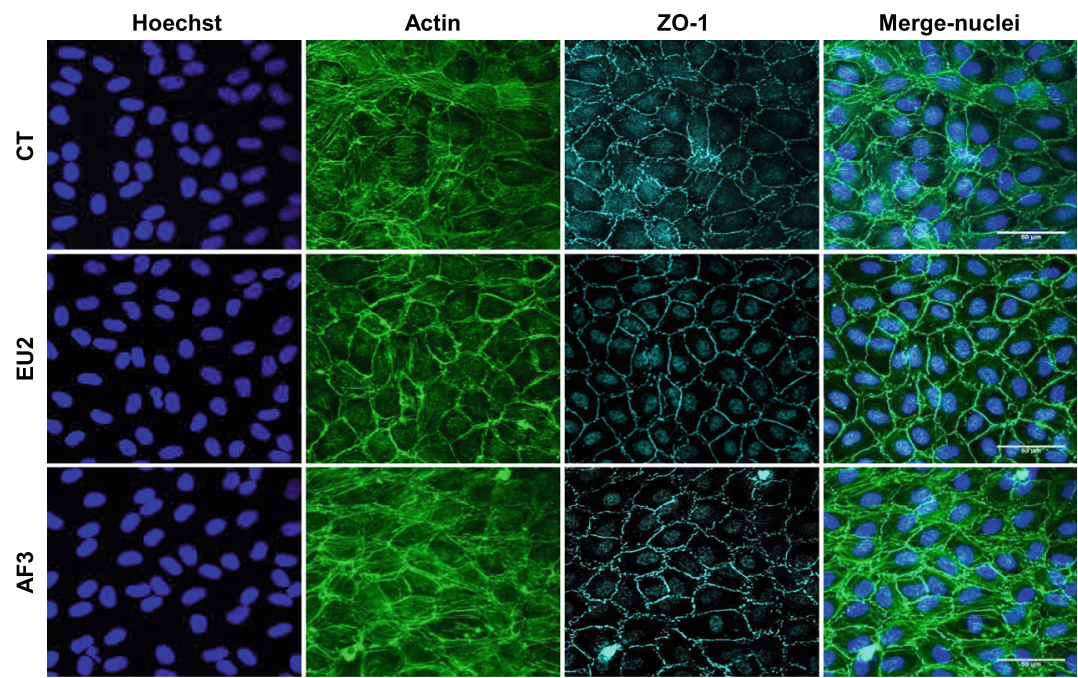

Fig. 8 USUV efficiently replicates in a human model of the blood-brain barrier without inducing alteration of endothelium integrity. a Human in vitro BBB model composed by CD34 $4^{+}$blood cord-derived endothelial cells cultured on transwell filters and placed on top of pericytes. $\mathbf{b}$ hBLECs were infected with USUV EU2 and AF3 at MOI 0.1. Viral titers from both compartments are indicated at 4, 7, and $10 \mathrm{dpi}\left({ }^{*} p<0.05\right.$, ${ }^{* *} p<$ 0.01). c Permeability (Pe) of the Lucifer Yellow (LY) paracellular marker and transendothelial electrical resistance (TEER) was measured at $10 \mathrm{dpi}$. Each point represents the mean \pm SEM of 3 independent experiments. NS = not significant. $\mathbf{d}$ Immunofluorescence of actin and Zonula occludens (Zo)-1 staining showing no perturbation of endothelium structure (10 dpi). Scale bar $=50 \mu \mathrm{m}$

pathogenicity, or neuroinvasiveness were then analyzed. USUV strains were compared to a WNV lineage 2 strain which circulated in Europe in 2018 (WNV L2): WNV6125 France 2018 (P2018-3687). Flaviviruses are described to have $\mathrm{N}$-linked glycosylation sites on their envelope proteins. Glycosylated E protein interacts with cell surface lectins, facilitating attachment and infectivity [50]. As expected, USUV strains have not N-linked glycosylation site at position N67 known to be unique to
DENV whereas in all strains we observed glycosylation at N154 (motif NYS) that is highly conserved among flaviviruses. All strains exhibited also the potentially more virulent proline at position NS1-250 [71]. As shown in Fig. 9b, the three potential $\mathrm{N}$-linked glycosylation sites at positions 130, 175, and 207 within the NS1 protein, all molecular determinants of neuroinvasiveness, could be identified in all strains as well. Concerning NS5, we observed, specifically in USUV EU2, an amino acid 


\section{A}

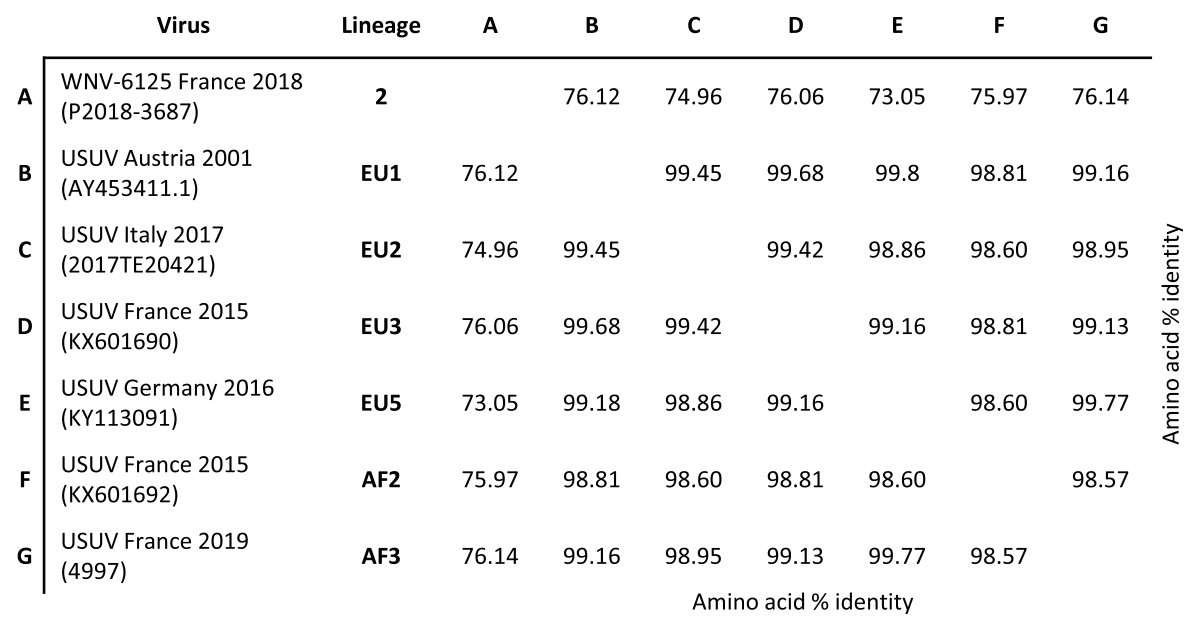

B

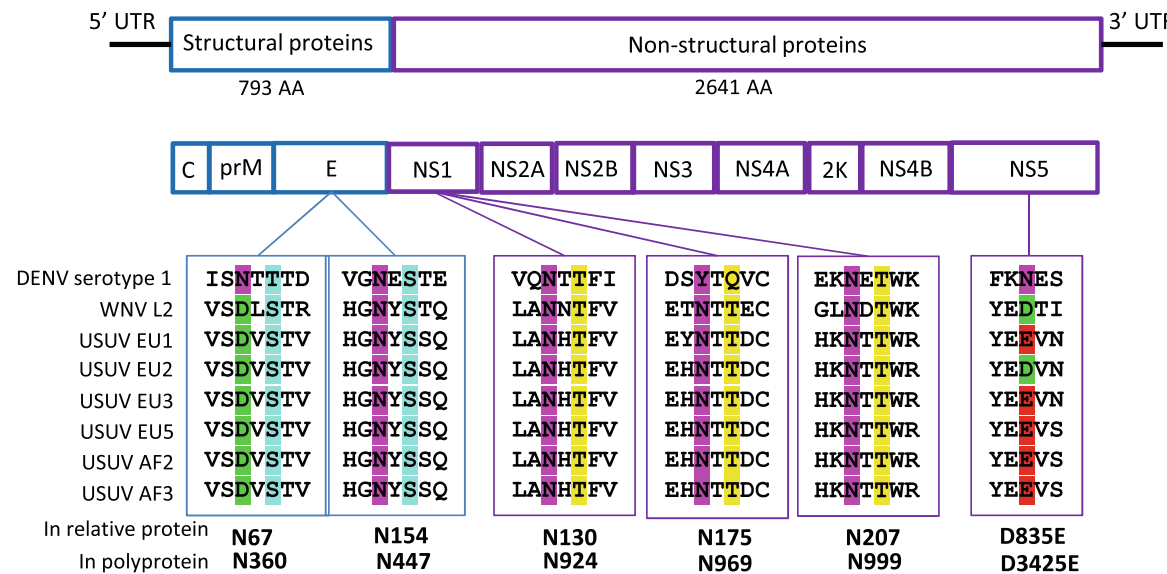

Fig. 9 Genetic diversity of USUV strains. a Amino acid \% identity of the viral polyprotein (MUSCLE, EMBL-EBI). Viral strains and associated lineage are indicated in the table. $\mathbf{b}$ Annotated viral genome and subsequent viral proteins are shown. A zoom on specific known virulence motifs is presented with amino acid position in the relative viral protein (up) or in the polyprotein (down). Each amino acid is highlighted with a specific color

substitution at position 3425 of the polyprotein, which corresponds to the residue position 835 of the NS5 protein (E3425D/E835D-NS5) (Fig. 9b). We also found this mutation in the second EU2 strain that we used in our study (data not shown). In addition, by analyzing other EU2 sequences available online, we found this mutation in 14/15 isolates (except for JF 266698). This suggests that this substitution could be a characteristic mutation of EU2 lineage. Interestingly, this mutation was previously described for an EU2 strain isolated from a patient with neuroinvasive disease [21]. More precisely, this mutation is localized in the RNA-dependent RNA polymerase domain of the NS5 protein that codes for the viral RNA polymerase. We also identified other unique mutations for EU2 strain (NS1: E36G, R57X, L85, NS2A: 108 T, NS4B: 133S, K349R, T325X, NS5: 55I).

\section{Discussion}

USUV is classified into eight distinct lineages, which can circulate simultaneously in certain areas, especially in Europe. USUV has been repeatedly introduced into Europe from Africa over the last 50 years [72]. Our observations suggest that different isolates from the 6 main USUV lineages can efficiently infect suckling immunocompetent Swiss mice and they all have the ability to access and replicate in the brain parenchyma. However, we reported different virulence profiles between the strains. In particular, the EU2 isolate appeared more pathogenic, 
whereas the AF3 strain had a significant delay in appearance of symptoms and mortality. One of our striking results is that the EU2 isolate, unlike the other isolates, induced symptoms similar of epileptic seizure including freezing, tremor, and tail erection. Seizures are commonly reported consequences of infection by several neurotropic viruses that can induce neuroinflammatory responses, leading to enhanced neuronal excitability and ultimately contributing to epileptogenesis. For example, another flavivirus ZIKV is known for its induction of epileptic seizures in neonatal infected mice [73]. Exacerbated inflammation could be a consequence as well as a cause of epilepsy, and several inflammatory mediators, such as IL1 $\beta$, TNF, and IL6, have been detected in surgically resected brain tissue from epileptic patients [74]. The major role of brain inflammation in the development of seizures has also been demonstrated in several models of infectious diseases [75]. However, given the fairly similar inflammatory profiles between the different European isolates in infected mice, exacerbated inflammation does not seem to be the only cause of the convulsive seizures observed following EU2 strain infection.

Viral infections of the CNS are dependent upon viral replication characteristics as well as immune responses to the virus. Once in the brain, neurotropic arboviruses can infect a variety of cells and lead to general neuroinflammation and eventually BBB impairment if cells of the neurovascular unit (NVU) as pericytes, or endothelial cells are targeted, as already described for JEV [76, 77] or DENV [78]. The concept of the NVU was defined by Harder [79] as a structure formed by neurons, astrocytes, pericytes, microglia, oligodendrocytes, and endothelial cells. Interactions occur between neural, glial, and vascular components of the NVU in response to physiological stimuli or neuroimmune responses. Overall, these interactions maintain CNS homeostasis. NVU cells are direct or indirect targets of neurotropic flaviviruses. Infection of these cells can induce the release of soluble mediators that are involved in neuroinflammation and, in some cases, disruption of the blood-brain barrier (BBB). However, CNS resident cells have developed innate antiviral immune strategies to defend against neurotropic viruses. If neurons are a major target, other cell types such as astrocytes, microglia, pericytes, and endothelial cells can also become infected and participate to the resolution of infection by generating immune responses. Microglia and astrocytes are the main cells in the CNS responsible for initiating, regulating, and maintaining neuroimmune responses to viral infections. Activated glial cells are known to produce numerous mediators, including cytokines and chemokines, that orchestrate both the defense against and the pathogenicity of CNS viral infections [80]. Astrocytes can be infected by different flaviviruses, including ZIKV, WNV, JEV, or tick-borne encephalitis virus (TBEV) [59, 81, 82], as well as USUV [56]. Interestingly, as observed in suckling immunocompetent Swiss mice, the EU2 USUV isolate also resulted in higher viral infection/replication in a large panel of neuronal cells. In this regard, EU2 infection resulted in higher susceptibility and proportion of infected cells in astrocytes, where we observed increased virulence with two different strains, suggesting that the effect is potentially lineage-dependent rather than straindependent. The ability of the USUV strains to differentially replicate in NVU cells may favor the capacity of the virus to undergo a second round of infection into the CNS. Thus, NVU cells may play a central role not only in the initial dissemination of different USUV strains to the CNS, but also in secondary waves of spread, both likely to exacerbate USUV-mediated neuropathology.

CNS cells express a number of PRRs and are able to respond to pathogen-associated molecular patterns (PAMPs; derived from pathogens) and to damageassociated molecular patterns (DAMPs; released upon CNS damage). USUV appears to induce a different cytokine response depending on the cell type and the strain. For example, the EU2 isolate replicated more efficiently and induced stronger cytokine responses in microglia, one of the main effector cells in neuroinflammation. The AF3 strain had a similar profile; nevertheless, it replicated for a shorter time in these cells. The fact that the EU2 strain replicates more and for a longer time compared to the other strains in several CNS cell types could explain the strong deleterious effect of the infection observed in vivo. The host innate antiviral response plays a central role in controlling viral replication. Following USUV infection, the inflammatory context is associated with an important antiviral response, as observed by upregulation of IFN $\beta$ in the infected brain and in neuronal cells. In infected astrocytes, there was increased expression of genes involved in the antiviral response, such as IFN $\beta$ and IRF3, mainly for EU1 and EU2 strain infections. Nonetheless, replication was also highest for these two strains. These results suggest that the IRF3dependent arm of the host antiviral response does not differentially restrict USUV strain replication within infected cells. Moreover, the host antiviral response appears to play a minimal role in the differential susceptibility of astrocytes to different USUV strains. The absence of an efficient protective effect of type 1 IFNs has been demonstrated for numerous other neurotropic flaviviruses, such as DENV and WNV [83]. Previous studies have shown the induction of antiviral responses despite USUV replication, suggesting that USUV does not harbor mechanisms that efficiently interfere with IFN induction [56]. The mechanisms used by USUV to interfere with this IFN response in order to 
establish a productive infection are currently not known. RIG-I, TLR3, and MDA5 are well-conserved cytoplasmic PRRs that detect viral RNAs during infection and activate the type I IFN-mediated antiviral immune response. RNA levels of PRRs generally increase in concert with viral infection and are considered to reflect pathway activation. While RIG-I or TLR3 were overexpressed following USUV infection and this did not vary strongly between different strains, MDA5 overexpression was greater in isolates with strong IFN $\beta$ induction, including the EU1, EU2, and AF3 strains.

Host innate responses leading to pro-inflammatory cytokine and chemokine production are thought to modulate BBB integrity and enable viruses to access the brain [84]. The brain endothelium constitutes a primary barrier to virus neuroinvasion. Using an in vitro BBB model that exhibits the physiological characteristics of the brain endothelium [48], we demonstrated that the EU2 isolate, the most virulent strain we tested, can infect and replicate in hBLEC. Here, viral particles were released in the basolateral compartment (which would correspond to the parenchymal side) for a prolonged time (unlike the AF3 strain), potentially increasing the capacity of the EU2 strain to cross the BBB. However, this isolate did not disturb endothelial integrity. It is generally suggested that for viral invasion BBB disruption is a pivotal event. Yet, numerous studies show that neurotropic flaviviruses can reach the CNS by crossing the $\mathrm{BBB}$ without breaking the barrier, allowing free virus to spread in the CNS. Our findings are consistent with reports that the capacity of virus to cross the BBB to reach the CNS is not systematically the determining factor for neuropathogenicity. Increasing evidence suggests that viral entry into the CNS is often a multistep process that can occur through one of several routes. Some neurotropic viruses can directly infect the endothelial cells of the brain and release viral particles into the parenchyma. Viral neuroinvasion can thus occur via replication of the virus within NVU cells prior to the breakdown of the $\mathrm{BBB}$. This mechanism is thought to be shared by neuroinvasive viruses, including the closely related flavivirus WNV, and enhances dissemination within the CNS [85]. Our results suggest that the differential invasion of the brain by the several different USUV strains does not seem to be linked to strain-dependent BBB disturbance, but rather to a different capacity to infect and replicate in the cells forming the BBB.

Another interesting observation is the presence of a specific and atypical CPE following EU2 lineage infection in all CNS components (with the exception of pericytes). The characteristics of CPE caused by flaviviruses vary according to the host cell and involved various factors, including viral receptors, host genetics, defective viral particles, and immune response [86]. CPE induced by
USUV is usually characterized by a diffuse CPE corresponding to cell rounding, shrinkage, and lysis. The atypical CPE we observed with two different isolates of EU2 was characterized by the presence of dead cells floating in clusters and could potentially be correlated with the higher virulence of this lineage. We could expect a relation between viral infectivity and virulence, $\mathrm{CPE}$ thus being unique to specific USUV lineages. Cellular and/or viral factors involved in this specific CPE induced by EU2 strains remain to be determined.

Virulence is an adaptive process and the result of interactions between numerous factors, involving both viral and host cell factors. These could include for example tropism, induction of neuronal apoptosis, resistance to interferon, regulation of cytokines and chemokines, induction of matrix metalloproteinase, quasi-species generation, or upregulation of major histocompatibility complex class I expression. It is therefore clear that virulence is a multifactorial process and many aspects need to be studied in order to elucidate viral pathogenicity. For example, the neuroinvasive potential of WNV is strain-dependent, but mainly due to differential strain ability to reach the CNS [43]. In some cases, this difference could also be due to different replication capacities in BBB cells or directly in neurons, as already demonstrated for WNV [59] and Semliki Forest Virus [87]. It is documented that there is a close relationship between European USUV strains (nucleotide identity 99\%) while there is a greater divergence between African USUV isolates (nucleotide identity 96\%). Several structural and nonstructural genes (prM, E, NS1, NS3, and NS5) have exhibited greater nucleotide than amino acid divergence [72]. The virulence of flaviviruses has often been associated with $E$ protein glycosylation [50] and glycosylation of the NS1 protein [88]. One possible viral factor of virulence is the presence of specific $\mathrm{N}$-linked glycans on the E protein, correlating thus with the ability to invade the CNS [43, 50, 89]. All strains analyzed exhibited classical markers of neurovirulence previously described, which is consistent with the fact that all of our strains are able to invade the brain. Nevertheless, we identified specific mutations in EU2 strain (NS1: E36G, R57X, L85, NS2A: 108 T, NS4B: 133S, K349R, T325X, NS5: 55I, E835D). The discovery of amino acid substitution in the RdRp domain of the NS5 protein (E3425D/ E835D-NS5) in both EU2 strains is particularly interesting, as this substitution is not seen in the other strains from other lineages. In addition, by analyzing other EU2 sequences available online, we found this mutation in 14/15 isolates (except for JF 266698). This suggests that this substitution could be a characteristic mutation of EU2 lineage. For instance, this aa change was also found in WNV and in other neurovirulent flaviviruses (JEV, Kunjin virus (KUNV), and Murray Valley encephalitis 
virus (MVEV)) and have been suggested to be related with viral neuroinvasiveness [21]. Furthermore, substitutions in virtually equivalent positions were associated with variation in the capacity of WNV to invade the CNS [21] and an E to D substitution in the NS5 protein of TBEV affects the virulence in mice underlying the contribution of viral $\mathrm{RdRp}$ to flavivirus neurovirulence [90]. This mutation was previously described in an EU2 strain isolated from a patient with neuroinvasive disease and was suggested to impact the efficiency of viral replication and virulence which our results seem to corroborate. Indeed, NS5 protein may have an effect on the efficiency of viral replication as its codes for the RNAdependent RNA polymerase involved in the replication complex [21]. Association of these several mutations with virulence remains to be elucidated. For this, reverse genetic systems will be helpful to allow the identification of the molecular and cellular mechanisms involved in USUV pathogenicity.

There is a strong probability that the strains used in this study were not derived due to extensive passaging (no more than 5 passages for all strains), so altogether our data indicate that there are intrinsic differences in the pathogenicity/virulence of USUV isolates in vivo and in vitro as previously described for other flaviviruses, such as ZIKV and WNV [41, 42]. Recent studies in rodents [91], immunocompetent mice [92], and chicken embryos [93] also demonstrate different results depending on the strain used. Is should be noted that no difference of mortality was reported in chicken embryos infected with several USUV strains [93]. This difference can be related to many factors (such as inoculation sites, number of viral passages, difference in models (birds versus mammals, embryos versus neonatal animals...). For this reason, it is important to investigate whether the differences in virulence observed in our models have clinical relevance. As reported in the literature, neurological complications are mainly described after infection with an EU2 strain, which is also a lineage frequently circulating in the south of Europe. It can consequently be hypothesized that the USUV EU2 lineage, characterized by a higher infection and viral production, longer persistence, and induction of an atypical CPE, could be more pathogenic for humans and/or birds and likely better adapted to the vector hosts.

\section{Conclusion}

In conclusion, our study on the pathogenic properties of USUV strains circulating in Europe contributes to a better understanding of USUV pathogenesis. To define the host and viral factors involved in pathogenesis, the naturally occurring diversity in virulence among viral strains provides a robust model system. Monitoring the global diversity and distribution of circulating USUV strains, as well as characterizing their neurotropism, will aid in the threat assessment and epidemiological modeling if future USUV outbreaks occur.

\section{Supplementary Information}

The online version contains supplementary material available at https://doi. org/10.1186/s12974-020-02060-4.

Additional file 1: Supplemental Figure 1. Two USUV EU2 strains induce a specific CPE and persistent viral replication in astrocytes. Supplemental Figure 2. Differential CPE in USUV-infected murine microglia and neurons cells. Supplemental Figure 3. USUV isolates induces CPE in human endothelial cells with an atypical shape for EU2 while there is no CPE in pericytes.

\section{Abbreviations}

AF: Africa; BBB: Blood-brain barrier; BRDU: Bromodeoxyuridine; C: Capsid; CNS: Central nervous system; CPE: Cytopathic effect; DAMPs: Damageassociated molecular patterns; DENV: Dengue virus; Dpi: Days post-infection; E: Envelope; ELISA: Enzyme-linked immunosorbent assay; EU: Europe; hBLEC: Human Brain-like Endothelial Cells; IFN: Interferon; Ifnar ${ }^{-1-}$ : Lacking the interferon type 1 receptor; IL1 $\beta$ : Interleukin 1 B; IL6: Interleukin 6; i.p.: Intraperitoneally; IRF3: Interferon regulatory factor 3; JEV: Japanese encephalitis virus; KUNV: Kunjin virus; LY: Lucifer Yellow; MDA5: Melanoma differentiation-associated antigen 5; MVEV: Murray Valley encephalitis virus; MTT: 3-(4,5-Dimethylthiazol-2-yl)-2,5-diphenyltetrazolium bromide; MYD88: Myeloid differentiation primary response 88; NVU: Neurovascular unit; ORF: Open reading frame; PAMPs: Pathogen-associated molecular patterns; PFA: Paraformaldehyde; prM/M: Pre-membrane/membrane; PRRs: Pattern recognition receptors; RHEM: Réseau d'Histologie Expérimentale de Montpellier; RIG-I: Retinoic acid-inducible gene I; RT-qPCR: Quantitative reverse transcriptase PCR assay; TBEV: Tick-borne encephalitis virus;

TCID50: Tissue culture infectious dose 50\%; TEER: Transendothelial electrical resistance; TLR: Toll-like receptor; TNFa: Tumor necrosis factor alpha; USUV: Usutu virus; WNV: West Nile virus; ZIKV: Zika virus

\section{Acknowledgements}

We thank the "Réseau d'Histologie Expérimentale de Montpellier" (RHEM) histology facility for their histology techniques and expertise, and we thank Morgane Broyon and Aurélie Covinhes for their technical assistance. We thank also the Montpellier Rio Imaging facility for the microscope imaging as well as Elisabetta Blasi and Hélène Hirbec for providing the BV2 microglia cell line.

\section{Authors' contributions}

$M C, O C, J B, C D, M F M, L M, V F$, and FG performed the experiments. LT and FM isolated the Europe 2 viral strains. YS designed the work and drafted the manuscript with MC. SS, PVD, DC, JSC, GS, SL, and GG substantively revised the manuscript. The authors read and approved the final manuscript.

\section{Funding}

This work was funded by REACTing (reference: YY/FC/2018-032) and Montpellier University of Excellence (MUSE) through ANR (the French National Research Agency) with the reference ANR-16-IDEX-0006 and the Labex EpiGenMed "Investissements d'avenir", program "ANR-10-LABX-12-01."

\section{Availability of data and materials}

All data generated or analyzed during this study are included in this published article and its supplementary information files.

\section{Ethics approval and consent to participate}

Mice were bred and maintained according to the European institutional guidelines (appendix A STE $n^{\circ} 123$ ) and the French Ministry of Agriculture. Experiments were approved by the French ethics committee (approval $\mathrm{N}^{\circ}$ 6773-201609161356607). The in vitro human BBB model requires the use of human cells obtained from donors. All parents signed an informed consent form, according to the French legislation (CODECOH Number DC2011-1321). 


\section{Consent for publication}

Not applicable.

\section{Competing interests}

The authors declare that they have no competing interests.

\section{Author details}

'Pathogenesis and Control of Chronic Infections, Université de Montpellier, INSERM, EFS, Montpellier, France. ${ }^{2}$ BioCommunication en CardioMétabolique (BC2M), Montpellier University, Montpellier, France. ${ }^{3}$ Université de Montpellier, CNRS, Viral Trafficking, Restriction and Innate Signaling, Montpellier, France. ${ }^{4}$ Bernhard Nocht Institute for Tropical Medicine, WHO Collaborating Centre for Arbovirus and Haemorrhagic Fever Reference and Research, 20359 Hamburg, Germany. ${ }^{5}$ OIE Reference Centre for West Nile Disease, Istituto Zooprofilattico Sperimentale "G. Caporale", 46100 Teramo, Italy. ${ }^{6}$ Faculty of Mathematics, Informatics and Natural Sciences, Universität Hamburg, 20148 Hamburg, Germany. ${ }^{7}$ Department of Biotechnology, INIA, Madrid, Spain. ${ }^{8}$ UPE, Anses Animal Health Laboratory, UMR1161 Virology, INRA, Anses, ENVA, Maisons-Alfort, France. ${ }^{9}$ Blood-Brain Barrier Laboratory (BBB Lab), University of Artois, UR2465, F-62300 Lens, France. ${ }^{10}$ Centre Hospitalier Universitaire de Montpellier, Montpellier, France.

Received: 18 August 2020 Accepted: 11 December 2020 Published online: 06 January 2021

\section{References}

1. McIntosh BM. Usutu (SAAr 1776); nouvel arbovirus du groupe B. Int Cat Arboviruses. 1985;3:1059-60.

2. Woodall J. The viruses isolated from arthropods at the East African Virus Research Institute in the 26 years ending December 1963. In: Proc E Afrc Acad; 1964. p. 141-6.

3. Calisher $\mathrm{CH}$, Gould EA. Taxonomy of the virus family Flaviviridae. Adv Virus Res. 2003:59:1-19.

4. Poidinger M, Hall RA, Mackenzie JS. Molecular characterization of the Japanese encephalitis serocomplex of the Flavivirus genus. Virology. 1996; 218:417-21.

5. Weissenböck H, Kolodziejek J, Url A, Lussy H, Rebel-Bauder B, Nowotny N. Emergence of Usutu virus, an African mosquito-borne Flavivirus of the Japanese encephalitis virus group, central Europe. Emerg Infect Dis. 2002; 8(7):652-6.

6. Chvala S, Kolodziejek J, Nowotny N, Weissenböck H. Pathology and viral distribution in fatal Usutu virus infections of birds from the 2001 and 2002 outbreaks in Austria. J Comp Pathol. 2004;131(2-3):176-85.

7. Becker $N$, Jöst H, Ziegler U, Eiden $M$, Höper D, Emmerich $P$, et al. Epizootic emergence of Usutu virus in wild and captive birds in Germany. PLoS One. 2012;7(2):e32604.

8. Bakonyi T, Erdélyi K, Ursu K, Ferenczi E, Csörgo T, Lussy H, et al. Emergence of usutu virus in Hungary. J Clin Microbiol. 2007:45:3870-4.

9. Calzolari M, Gaibani P, Bellini R, Defilippo F, Pierro A, Albieri A, et al. Mosquito, bird and human surveillance of West Nile and Usutu viruses in Emilia-Romagna Region (Italy) in 2010. Coffey LL, editor. PLoS One. 2012;7: e38058 Available from: http://www.ncbi.nlm.nih.gov/pubmed/22666446. Cited 2018 Nov 20.

10. Bakonyi T, Gould EA, Kolodziejek J, Weissenböck H, Nowotny N. Complete genome analysis and molecular characterization of Usutu virus that emerged in Austria in 2001: Comparison with the South African Strain SAAR-1776 and other flaviviruses. Virology. 2004;328(2):301-10.

11. Pfeffer M, Dobler G. Emergence of zoonotic arboviruses by animal trade and migration. Parasit Vectors. 2010;3(1):35 BioMed Central.

12. Decors A, Beck C, Lemberger $K$, Eraud C, Desvaux S, Chaigneau P, Baurier F, Blanchard Y, Lecollinet S. 2018, en France : record de circulation du virus Usutu. Faune Sauvage. 2019;324:9-14.

13. Lelli R, Savini G, Teodori L, Filipponi G, Di Gennaro A, Leone A, et al. Serological evidence of USUTU virus occurrence in north-eastern Italy. Zoonoses Public Health. 2008;55(7):361-7.

14. Cadar D, Becker N, de Mendonca Campos R, Börstler J, Jöst H, SchmidtChanasit J. Usutu virus in bats, Germany, 2013. Emerg Infect Dis. 2014;20(10): 1771-3.

15. Blázquez AB, Escribano-Romero E, Martín-Acebes MA, Petrovic T, Saiz JC. Limited susceptibility of mice to Usutu virus (USUV) infection and induction of flavivirus cross-protective immunity. Virology. 2015;482:67-71 Elsevier Inc.
16. Durand B, Haskouri H, Lowenski S, Vachiery N, Beck C, Lecollinet S. Seroprevalence of West Nile and Usutu viruses in military working horses and dogs, Morocco, 2012: dog as an alternative WNV sentinel species? Epidemiol Infect. 2016;144:1857-64 Available from: http://www.journals. cambridge.org/abstract_S095026881600011X. Cited 2018 Aug 18.

17. Bournez L, Umhang G, Faure E, Boucher J-M, Boué F, Jourdain $E$, et al. Exposure of wild ungulates to the Usutu and tick-borne encephalitis viruses in France in 2009-2014: evidence of undetected Flavivirus circulation a decade ago. Viruses. 2020;12:10 Available from: www.mdpi.com/journal/ viruses. Cited 2020 May 20

18. Nikolay B, Diallo M, Boye CSB, Sall AA. Usutu virus in Africa. Vector-Borne Zoonotic Dis. 2011;11:1417-23 Available from: http://www.ncbi.nlm.nih.gov/ pubmed/21767160. Cited 2018 Mar 8.

19. Pecorari M, Longo G, Gennari W, Grottola A, Sabbatini AMT, Tagliazucchi S. Rapid communications first human case of Usutu virus neuro invasive infection, Italy, August - September 2009; 2009. p. 5-6.

20. Cavrini F, Gaibani P, Longo G, Pierro AM, Rossini G, Bonilauri P, et al. Usutu virus infection in a patient who underwent orthotropic liver transplantation, Italy, August-September 2009. Euro Surveill. 2009:14 Available from: https:// www.ncbi.nlm.nih.gov/m/pubmed/20070935/?i=3\&from=cavrini 2009 eurosurveillance. Cited 2018 Apr 2.

21. Gaibani P, Cavrini F, Gould EA, Rossini G, Pierro A, Landini MP, et al. Comparative genomic and phylogenetic analysis of the first Usutu virus isolate from a human patient presenting with neurological symptoms. PLoS One. 2013;8(5):e64761.

22. Cavrini F, Della Pepa ME, Gaibani P, Pierro AM, Rossini G, Landini MP, et al. A rapid and specific real-time RT-PCR assay to identify Usutu virus in human plasma, serum, and cerebrospinal fluid. J Clin Virol. 2011;50:221-3 Available from: http://linkinghub.elsevier.com/retrieve/pii/S1386653210004592. Cited 2018 Apr 2.

23. Grottola A, Marcacci M, Tagliazucchi S, Gennari W, Di Gennaro A, Orsini M, et al. Usutu virus infections in humans: a retrospective analysis in the municipality of Modena, Italy. Clin Microbiol Infect. 2017;23:33-7.

24. Caracciolo I, Mora-Cardenas E, Aloise C, Carletti T, Segat L, Burali MS, et al. Comprehensive response to Usutu virus following first isolation in blood donors in the Friuli Venezia Giulia region of Italy: development of recombinant NS1-based serology and sensitivity to antiviral drugs. PLoS Negl Trop Dis. 2020; 14:e0008156 Public Library of Science. Bowen RA, editor. Available from: https://dx.plos.org/10.1371/journal.pntd.0008156. Cited 2020 May 18.

25. Percivalle E, Cassaniti I, Sarasini A, Rovida F, Adzasehoun KMG, Colombini I, et al. West nile or usutu virus? A three-year follow-up of humoral and cellular response in a group of asymptomatic blood donors. Viruses. 2020; 12(2):157 MDPI AG.

26. Carletti F, Colavita F, Rovida F, Percivalle E, Baldanti F, Ricci l, et al. Expanding usutu virus circulation in italy: detection in the Lazio region, central Italy, 2017 to 2018. Euro Surveill. 2019;24(3):1800649 European Centre for Disease Prevention and Control (ECDC).

27. Pacenti M, Sinigaglia A, Martello T, De Rui E, Franchin E, Pagni S, et al, Clinical and virological findings in patients with Usutu virus infection, northern Italy, 2018. Euro Surveill. 2019;24 Available from: https://www. eurosurveillance.org/content/10.2807/1560-7917.ES.2019.24.47.1900180. Cited 2019 Nov 28.

28. Nagy A, Mezei E, Nagy O, Bakonyi T, Csonka N, Kaposi M, et al. Extraordinary increase in West Nile virus cases and first confirmed human Usutu virus infection in Hungary, 2018. Euro Surveill. 2019;24(28):1900038 European Centre for Disease Control and Prevention (ECDC).

29. Santini M, Vilibic-Cavlek T, Barsic B, Barbic L, Savic V, Stevanovic V, et al. First cases of human Usutu virus neuroinvasive infection in Croatia, August, September 2013: clinical and laboratory features. J Neurovirol. 2014;21:92-7.

30. Vilibic-Cavlek T, Savic V, Sabadi D, Peric L, Barbic L, Klobucar A, et al. Prevalence and molecular epidemiology of West Nile and Usutu virus infections in Croatia in the 'One health' context, 2018. Transbound Emerg Dis. 2019;66:1946-57 Blackwell Publishing Ltd.

31. Simonin $Y$, Sillam O, Carles MJ, Gutierrez $S$, Gil $P$, Constant $O$, et al. Human Usutu virus infection with atypical neurologic presentation, Montpellier, France, 2016. Emerg Infect Dis. 2018;24 Available from: http://wwwnc.cdc. gov/eid/article/24/5/17-1122_article.htm. Cited 2018 Apr 5.

32. Bakonyi T, Jungbauer C, Aberle SW, Kolodziejek J, Dimmel K, Stiasny K, et al. Usutu virus infections among blood donors, Austria, July and August 2017 raising awareness for diagnostic challenges. Euro Surveill. 2017;22(41):1700644. 
33. Aberle SW, Kolodziejek J, Jungbauer C, Stiasny K, Aberle JH, Zoufaly A, et al. Increase in human West Nile and Usutu virus infections, Austria, 2018. Euro Surveill. 2018;23:1800545 Available from: https://www.eurosurveillance.org/ content/10.2807/1560-7917.ES.2018.23.43.1800545. Cited 2018 Nov 1.

34. Cadar D, Maier P, Müller S, Kress J, Chudy M, Bialonski A, et al. Blood donor screening for West Nile virus (WNV) revealed acute Usutu virus (USUV) infection, Germany, September 2016. Euro Surveill. 2017;22:30501 Available from: http://www.eurosurveillance.org/NiewArticle.aspx?Articleld=22764. Cited 2018 Apr 2.

35. Domanović D, Gossner CM, Lieshout-Krikke R, Mayr W, Baroti-Toth K, Dobrota AM, et al. West nile and usutu virus infections and challenges to blood safety in the European Union. Emerg Infect Dis. 2019;25:1050-7 Centers for Disease Control and Prevention (CDC).

36. Zaaijer HL, Slot E, Molier M, Reusken CBEM, Koppelman MHGM. Usutu virus infection in Dutch blood donors. Transfusion. 2019;59:2931-7 Blackwell Publishing Inc.

37. Clé M, Beck C, Salinas S, Lecollinet S, Gutierrez S, Van de Perre P, et al. Usutu virus: a new threat? Epidemiol Infect. 2019;147:e232 Available from: http:// www.ncbi.n/m.nih.gov/pubmed/31364580. Cited 2019 Aug 29.

38. Cadar D, Lühken R, van der Jeugd H, Garigliany M, Ziegler U, Keller M, et al. Widespread activity of multiple lineages of Usutu virus, Western Europe, 2016. Euro Surveill. 2017;22(4):30452.

39. Vilibic-Cavlek T, Petrovic T, Savic V, Barbic L, Tabain I, Stevanovic V, et al. Epidemiology of usutu virus: the european scenario. Pathogens. 2020:1-19 MDPI AG. Available from: https://pubmed.ncbi.nlm.nih.gov/32858963/. Cited 2020 Nov 13.

40. Nikolay B, Dupressoir A, Firth C, Faye O, Boye CS, Diallo M, et al. Comparative full length genome sequence analysis of Usutu virus isolates from Africa. Virol J. 2013;10:1 Available from: Virology Journal.

41. Pérez-Ramírez E, Llorente F, Del Amo J, Fall G, Sall AA, Lubisi A, et al Pathogenicity evaluation of twelve West Nile virus strains belonging to four lineages from five continents in a mouse model: discrimination between three pathogenicity categories. J Gen Virol. 2017;98:662-70 Microbiology Society.

42. Simonin $Y$, van Riel D, Van de Perre P, Rockx B, Salinas S. Differential virulence between Asian and African lineages of Zika virus. PLoS Negl Trop Dis. 2017;11:e0005821 Rico-Hesse R, editor. Available from: http://www.ncbi. nlm.nih.gov/pubmed/28934211. Cited 2018 Feb 21.

43. Beasley DWC, Li L, Suderman MT, Barrett ADT. Mouse neuroinvasive phenotype of West Nile virus strains varies depending upon virus genotype. Virology. 2002;296:17-23 Academic Press. Available from: http://linkinghub. elsevier.com/retrieve/pii/S0042682202913723. Cited 2016 Jul 8.

44. Kärber G. Beitrag zur kollektiven Behandlung pharmakologischer Reihenversuche. Naunyn Schmiedebergs Arch Exp Pathol Pharmakol. 1931; 162:480-3 Springer-Verlag.

45. Clé M, Barthelemy J, Desmetz C, Foulongne V, Lapeyre L, Bolloré K, et al. Study of Usutu virus neuropathogenicity in mice and human cellular models. PLoS Negl Trop Dis. 2020;14:e0008223 Public Library of Science (PLOS).

46. Nikolay B, Weidmann M, Dupressoir A, Faye O, Boye CS, Diallo M, et al. Development of a Usutu virus specific real-time reverse transcription PCR assay based on sequenced strains from Africa and Europe. J Virol Methods. 2014;197:51-4 Available from: http://linkinghub.elsevier.com/retrieve/pii/ S0166093413003868. Cited 2018 Apr 2.

47. Blasi E, Barluzzi R, Bocchini V, Mazzolla R, Bistoni F. Immortalization of murine microglial cells by a $\mathrm{v}$-raf / $\mathrm{v}$-myc carrying retrovirus. J Neuroimmunol. 1990;27:229-37 Available from: https://pubmed.ncbi.nlm. nih.gov/2110186/. Cited 2020 Jun 23.

48. Cecchelli R, Aday S, Sevin E, Almeida C, Culot M, Dehouck L, et al. A stable and reproducible human blood-brain barrier model derived from hematopoietic stem cells. PLoS One. 2014;9(6):e99733 Public Library of Science.

49. Candela P, Saint-Pol J, Kuntz M, Boucau MC, Lamartiniere Y, Gosselet F, et al. In vitro discrimination of the role of LRP1 at the BBB cellular level: focus on brain capillary endothelial cells and brain pericytes. Brain Res. 2015;1594:1526 Elsevier.

50. Carbaugh DL, Lazear HM. Flavivirus envelope protein glycosylation: impacts on viral infection and pathogenesis; 2020.

51. Morrison TE, Diamond MS. Animal models of Zika virus infection, pathogenesis, and immunity. J Virol. 2017;91 Available from: http://www. ncbi.nlm.nih.gov/pubmed/28148798. Cited 2019 Sep 13.
52. Zompi S, Harris E. Animal models of dengue virus infection. Viruses. 2012; 4(1):62-82 Multidisciplinary Digital Publishing Institute (MDPI).

53. Samuel MA, Diamond MS. Alpha/beta interferon protects against lethal West Nile virus infection by restricting cellular tropism and enhancing neuronal survival. J Virol. 2005;79:13350-61.

54. Johnson AJ, Roehrig JT. New mouse model for dengue virus vaccine testing. J Virol. 1999;73:783 American Society for Microbiology (ASM).

55. Weissenböck H, Bakonyi T, Chvala S, Nowotny N. Experimental Usutu virus infection of suckling mice causes neuronal and glial cell apoptosis and demyelination. Acta Neuropathol. 2004;108:453-60.

56. Salinas S, Constant O, Desmetz C, Barthelemy J, Lemaitre J-M, Milhavet O, et al. Deleterious effect of Usutu virus on human neural cells. PLoS Negl Trop Dis. 2017;11:e0005913 Beasley DWC, editor. Available from: http://dx. plos.org/10.1371/journal.pntd.0005913. Cited 2018 Feb 21.

57. Ramesh G, Maclean AG, Philipp MT. Cytokines and chemokines at the crossroads of neuroinflammation, neurodegeneration, and neuropathic pain. Mediators Inflamm. 2013;2013:20 Hindawi Publishing Corporation.

58. Bhowmick S, Duseja R, Das S, Appaiahgiri MB, Vrati S, Basu A. Induction of IP-10 (CXCL10) in astrocytes following Japanese encephalitis. Neurosci Lett. 2007:414:45-50.

59. Hussmann KL, Samuel MA, Kim KS, Diamond MS, Fredericksen BL. Differential replication of pathogenic and nonpathogenic strains of West Nile virus within astrocytes. J Virol. 2013;87:2814-22 American Society for Microbiology.

60. Bruno V, Copani A, Besong G, Scoto G, Nicoletti F. Neuroprotective activity of chemokines against $\mathrm{N}$-methyl-D-aspartate or $\beta$-amyloid-induced toxicity in culture. Eur J Pharmacol. 2000;399:117-21 Elsevier.

61. Nakayama T, Shirane J, Hieshima K, Shibano M, Watanabe M, Jin Z, et al. Novel antiviral activity of chemokines. Virology. 2006;350:484-92 Academic Press.

62. Le Goffic R, Pothlichet J, Vitour D, Fujita T, Meurs E, Chignard M, et al. Cutting edge: influenza A virus activates TLR3-dependent inflammatory and RIG-I-dependent antiviral responses in human lung epithelial cells. J Immunol. 2007;178:3368-72 The American Association of Immunologists.

63. Henn A, Lund S, Hedtjärn M, Schrattenholz A, Pörzgen P, Leist M. The suitability of BV2 cells as alternative model system for primary microglia cultures or for animal experiments examining brain inflammation. ALTEX. 2009;26(2):83-94.

64. Michiels C. Endothelial cell functions. J Cell Physiol. 2003;196:430-43 John Wiley \& Sons, Ltd. Available from: http://doi.wiley.com/10.1002/jcp.10333. Cited 2020 May 26.

65. Balabanov R, Dore-Duffy P. Role of the CNS microvascular pericyte in the blood-brain barrier. J Neurosci Res. 1998;53:637-44 John Wiley \& Sons, Ltd.

66. Wang K, Wang H, Lou W, Ma L, Li Y, Zhang N, et al. IP-10 promotes bloodbrain barrier damage by inducing tumor necrosis factor alpha production in Japanese encephalitis. Front Immunol. 2018;9:1148.

67. Spindler KR, Hsu TH. Viral disruption of the blood-brain barrier. Trends Microbiol. 2012;20:282-90 Elsevier Ltd.

68. Verma S, Kumar M, Gurjav U, Lum S, Nerurkar VR. Reversal of West Nile virus-induced blood-brain barrier disruption and tight junction proteins degradation by matrix metalloproteinases inhibitor. Virology. 2010;397: 130-8.

69. Wimmer I, Tietz S, Nishihara H, Deutsch U, Sallusto F, Gosselet F, et al. PECA M-1 stabilizes blood-brain barrier integrity and favors paracellular T-cell diapedesis across the blood-brain barrier during neuroinflammation. Front Immunol. 2019;10:711 Frontiers Media S.A.

70. Loureiro JA, Andrade S, Duarte A, Neves AR, Queiroz JF, Nunes C, et al. Resveratrol and grape extract-loaded solid lipid nanoparticles for the treatment of Alzheimer's disease. Molecules. 2017;22(2):277 MDPI AG.

71. Hall RA, Khromykh AA, Mackenzie JM, Scherret JH, Khromykh TI, Mackenzie JS. Loss of dimerisation of the nonstructural Protein NS1 of Kunjin virus delays viral replication and reduces virulence in mice, but still allows secretion of NS1. Virology. 1999;75:66-75.

72. Engel D, Jöst H, Wink M, Börstler J, Bosch S, Garigliany MM, et al. Reconstruction of the evolutionary history and dispersal of Usutu virus, a neglected emerging arbovirus in Europe and Africa. MBio. 2016;7:1-12.

73. De Oliveira Souza IN, Frost PS, França JV, Nascimento-Viana JB, Neris RLS, Freitas L, et al. Acute and chronic neurological consequences of early-life zika virus infection in mice. Sci Transl Med. 2018;10 American Association for the Advancement of Science. Available from: https://pubmed.ncbi.n/m.nih. gov/29875203/. Cited 2020 Jun 23. 
74. Vezzani A, French J, Bartfai T, Baram TZ. The role of inflammation in epilepsy. Nat Rev Neurol. 2011;7(1):31-40.

75. Kirkman NJ, Libbey JE, Wilcox KS, White HS, Fujinami RS. Innate but not adaptive immune responses contribute to behavioral seizures following viral infection. Epilepsia. 2010;51:454-64 Available from: https://pubmed.ncbi.nlm. nih.gov/19845729/. Cited 2020 Jul 1.

76. Chen C-J, Ou Y-C, Li J-R, Chang C-Y, Pan H-C, Lai C-Y, et al. Infection of pericytes in vitro by Japanese encephalitis virus disrupts the integrity of the endothelial barrier. J Virol. 2014;88:1150-61.

77. Chang $C Y, L i J R$, Chen WY, Ou YC, Lai CY, Hu YH, et al. Disruption of in vitro endothelial barrier integrity by Japanese encephalitis virus-infected astrocytes. Glia. 2015;63:1915-32 John Wiley and Sons Inc.

78. Bhatt RS, Kothari ST, Gohil DJ, D'Souza M, Chowdhary AS. Novel evidence of microglial immune response in impairment of Dengue infection of CNS. Immunobiology. 2015;220:1170-6 Elsevier GmbH.

79. Harder DR, Zhang C, Gebremedhin D. Astrocytes function in matching blood flow to metabolic activity. News Physiol Sci. 2002;17:27-31.

80. Rock B, Gekker G, Hu S, Sheng WS, Cheeran M, Lokensgard JR, et al. Role of microglia in central nervous system infections. Clin Microbiol Rev. 2004;17: 942-64.

81. Palus M, Bilý T, Elsterová J, Langhansová $\mathrm{H}$, Salát J, Vancová M, et al. Infection and injury of human astrocytes by tick-borne encephalitis virus. J Gen Virol. 2014;95:2411-26 Microbiology Society.

82. Simonin Y, Loustalot F, Desmetz C, Foulongne V, Constant O, Fournier-Wirth C, et al. Zika virus strains potentially display different infectious profiles in human neural cells. EBioMedicine. 2016:12:161-9 Elsevier B.V.

83. Ye J, Zhu B, Fu ZF, Chen H, Cao S. Immune evasion strategies of flaviviruses. Vaccine. 2013;31(3):461-71.

84. Wang T, Town T, Alexopoulou L, Anderson JF, Fikrig E, Flavell RA. Toll-like receptor 3 mediates West Nile virus entry into the brain causing lethal encephalitis. Nat Med. 2004;10:1366-73.

85. Morrey JD, Olsen AL, Siddharthan V, Motter NE, Wang H, Taro BS, Chen D, Ruffner D, Hall JO. Increased blood-brain barrier permeability is not a primary determinant for lethality of West Nile virus infection in rodents. J. Gen. Virol. 2008:89:467-7. https://doi.org/10.1099/vir.0.83345-0.

86. Virology DB-IF, 2001 undefined. Flaviviruses. ci.nii.ac.jp. Available from: https:/ci.nii.ac.jp/naid/10012861997/. Cited 2020 Jun 23.

87. Fazakerley J. Pathogenesis of Semliki Forest virus encephalitis. Artic J Neurovirol. 2003; Available from: https://www.researchgate.net/publication/1 0983327. Cited 2020 May 18.

88. Whiteman MC, Wicker JA, Kinney RM, Huang CYH, Solomon T, Barrett ADT Multiple amino acid changes at the first glycosylation motif in NS1 protein of West Nile virus are necessary for complete attenuation for mouse neuroinvasiveness. Vaccine. 2011;29:9702-10 Available from: https:// pubmed.ncbi.nlm.nih.gov/21945257/. Cited 2020 Jun 23.

89. Botha EM, Markotter W, Wolfaardt M, Paweska JT, Swanepoel R, Palacios G et al. Genetic determinants of virulence in pathogenic lineage 2 West Nile virus strains. Emerg Infect Dis. 2008;14:222-30 Centers for Disease Control and Prevention (CDC). Available from: https://pubmed.ncbi.nlm.nih.gov/1 8258114/. Cited 2020 Jun 23.

90. Eyer L, Nougairede A, Uhliřova M, Driouich JS, Zouharova D, Valdes JJ, et al. An E460D substitution in the NS5 protein of tick-borne encephalitis virus confers resistance to the inhibitor galidesivir (BCX4430) and also attenuates the virus for mice. J Virol. 2019;93 American Society for Microbiology. Available from: https://www.ncbi.nlm.nih.gov//pmc/articles/PMC6675905/ ?report=abstract. Cited 2020 Nov 12.

91. Diagne M, Ndione M, Di Paola N, Fall G, Bedekelabou A, Sembène $P$, et al. Usutu virus isolated from rodents in Senegal. Viruses. 2019;11:181 Available from: http://www.ncbi.nlm.nih.gov/pubmed/30795524. Cited 2019 Feb 25.

92. Benzarti E, Sarlet M, Franssen M, Desmecht D, Schmidt-Chanasit J, Garigliany MM. New insights into the susceptibility of immunocompetent mice to Usutu virus. Viruses. 2020;12(2):189 MDPI AG.

93. Benzarti E, Rivas J, Sarlet M, Franssen M, Moula N, Savini G, et al. Usutu virus infection of embryonated chicken eggs and a chicken embryo-derived primary cell line. Viruses. 2020;12(5):531.

\section{Publisher's Note}

Springer Nature remains neutral with regard to jurisdictional claims in published maps and institutional affiliations.

\section{Ready to submit your research? Choose BMC and benefit from:}

- fast, convenient online submission

- thorough peer review by experienced researchers in your field

- rapid publication on acceptance

- support for research data, including large and complex data types

- gold Open Access which fosters wider collaboration and increased citations

- maximum visibility for your research: over $100 \mathrm{M}$ website views per year

At $\mathrm{BMC}$, research is always in progress.

Learn more biomedcentral.com/submissions 